\title{
A Critical Review for an Accurate Electrochemical Stability Window Measurement of Solid Polymer and Composite Electrolytes
}

\author{
Adrien Méry, Steeve Rousselot, David Lepage and Mickaël Dollé *(D)
}

Département de Chimie, Université de Montréal, 1375 Avenue Thérèse-Lavoie-Roux, Montréal, QC H2V 0B3, Canada; adrien.mery@umontreal.ca (A.M.); steeve.rousselot@umontreal.ca (S.R.); david.lepage.3@umontreal.ca (D.L.)

* Correspondence: mickael.dolle@umontreal.ca; Tel.: +1-514-343-7054

Citation: Méry, A.; Rousselot, S.;

Lepage, D.; Dollé, M. A Critical

Review for an Accurate Electrochemical Stability Window Measurement of Solid Polymer and Composite

Electrolytes. Materials 2021, 14, 3840.

https://doi.org/10.3390/ma14143840

Academic Editor: Changshin Jo

Received: 1 June 2021

Accepted: 7 July 2021

Published: 9 July 2021

Publisher's Note: MDPI stays neutral with regard to jurisdictional claims in published maps and institutional affiliations.

Copyright: (c) 2021 by the authors. Licensee MDPI, Basel, Switzerland. This article is an open access article distributed under the terms and conditions of the Creative Commons Attribution (CC BY) license (https:// creativecommons.org/licenses/by/ $4.0 /)$.
Abstract: All-solid-state lithium batteries (ASSLB) are very promising for the future development of next generation lithium battery systems due to their increased energy density and improved safety. ASSLB employing Solid Polymer Electrolytes (SPE) and Solid Composite Electrolytes (SCE) in particular have attracted significant attention. Among the several expected requirements for a battery system (high ionic conductivity, safety, mechanical stability), increasing the energy density and the cycle life relies on the electrochemical stability window of the SPE or SCE. Most published works target the importance of ionic conductivity (undoubtedly a crucial parameter) and often identify the Electrochemical Stability Window (ESW) of the electrolyte as a secondary parameter. In this review, we first present a summary of recent publications on SPE and SCE with a particular focus on the analysis of their electrochemical stability. The goal of the second part is to propose a review of optimized and improved electrochemical methods, leading to a better understanding and a better evaluation of the ESW of the SPE and the SCE which is, once again, a critical parameter for high stability and high performance ASSLB applications.

Keywords: electrochemical stability window; solid polymer electrolyte; solid composite electrolyte

\section{Introduction}

Li-ion batteries have been marketed since the early 1990s for several common applications, especially in portable devices and more recently for transportation and stationary power storage [1]. Compared with other energy storage devices, lithium-ion batteries have demonstrated many advantages including good energy density and long cycle life. However, even if a lot of progress has been made in recent years (for instance, efficient electric vehicles are presently available on the market), commercial batteries still need to be improved to achieve high energy and power densities while complying with safety requirements [2]. These current limitations are partly due to the restrictions imposed by electrode materials but also due to the poor stability (thermal, chemical, electrochemical, etc.) of liquid electrolytes. Indeed, the typical mixture of liquid alkyl carbonate solvents and lithium salts present in traditional Li-ion batteries is highly flammable and may lead to critical safety issues [2,3]. Thus, improving the safety of Lithium batteries is an important parameter that has concerned both the industrial and scientific communities for many years.

Thereby, the research on the development of new Lithium battery systems such as All Solid-State Lithium Batteries (ASSLB) has greatly increased since the early 2000s (Figure 1). In these devices, the traditional organic liquid electrolyte is replaced by a solid electrolyte that is both non-flammable and highly thermally stable. Furthermore, as no liquid is used in solid electrolytes, the entire battery packaging can be simplified, reducing dead weight, which results in an increase of the gravimetric and volumetric energy densities [4]. 


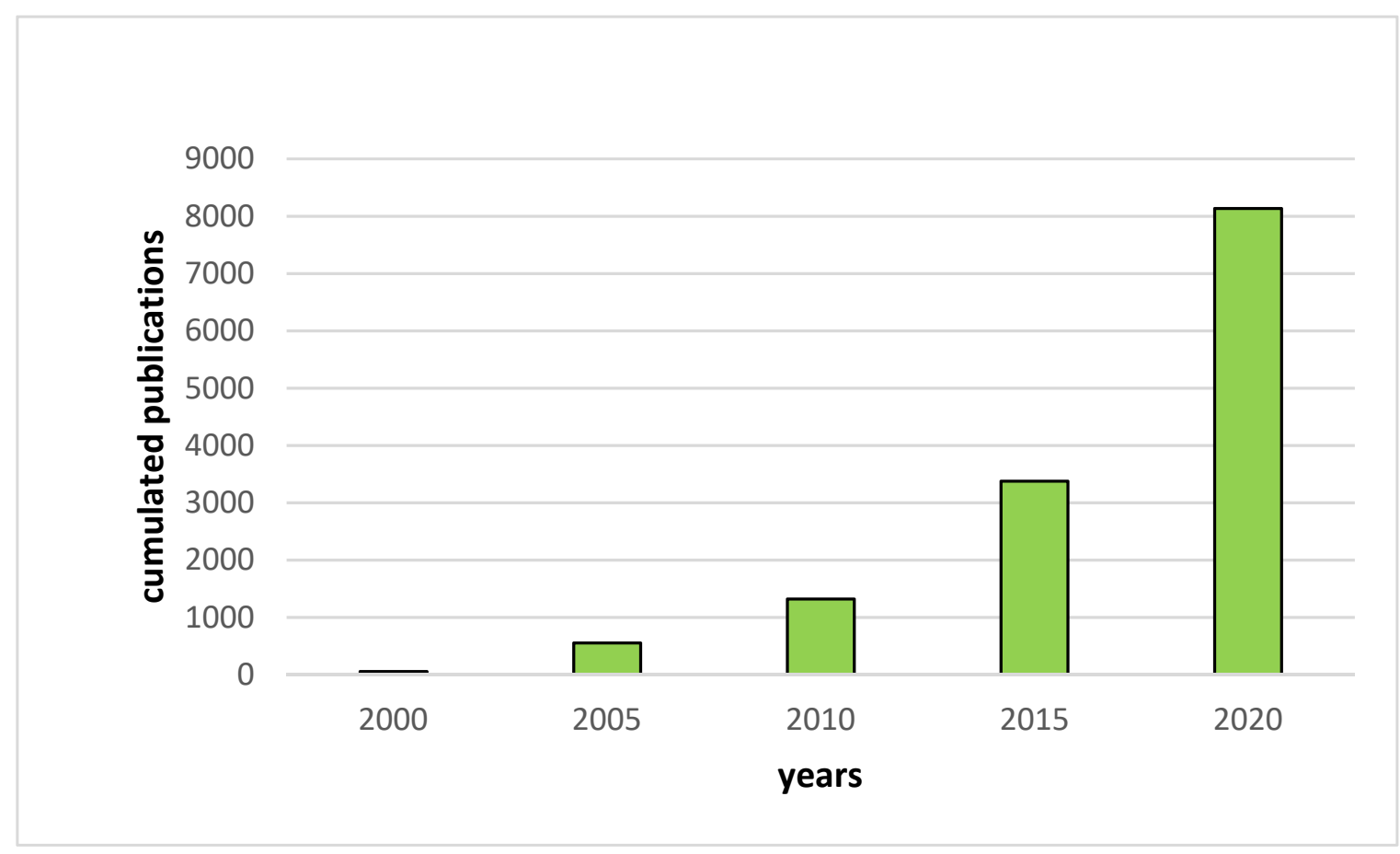

Figure 1. Evolution of the number of publications per year based on Web of Science results for "all solid-state battery".

To date, three major categories of solid electrolytes (SE) have been developed: Inorganic Solid Electrolytes (ISE), Solid Polymer Electrolytes (SPE) and Solid Composite Electrolytes (SCE) [5]. ISEs generally have better ionic conductivities and lithium transference numbers than SPEs, but the latter present more flexibility, better processability and generally a good interfacial contact with the electrode materials, whether it is lithium metal or a composite electrode [6]. SCEs, which are a mix of ISE and SPE, tend to present the best properties of both SPEs and SCEs. Solid electrolytes must respect specific requirements:

- possess high ionic conductivities (around $10^{-3}-10^{-4} \mathrm{~S} / \mathrm{cm}$ at room temperature);

- negligible electronic conductivity;

- have high ionic transference number;

- have high mechanical and chemical stability;

- $\quad$ and possess a high Electrochemical Stability Window (ESW).

Most publications mainly focus on the ionic conductivities and transport properties of electrolytes before implementing them in full systems (usually using $\mathrm{LiFePO}_{4}$ (LFP), $\mathrm{LiMn}_{2} \mathrm{O}_{4}(\mathrm{LMO})$ or $\mathrm{LiNi}_{x} \mathrm{Mn}_{\mathrm{y}} \mathrm{Co}_{\mathrm{z}} \mathrm{O}_{2}$ (NMC) as a positive electrode and $\mathrm{Li}$, $\mathrm{Li}-\mathrm{In}$ or $\mathrm{Li}_{4} \mathrm{Ti}_{5} \mathrm{O}_{12}$ as a negative electrode). One of the current objectives for ASSLBs, and consequently the aim of the solid electrolyte, is to be able to operate at a high potential with high voltage cathode materials (NMC, NCA) working above $4.2 / 4.3 \mathrm{~V} \mathrm{vs.} \mathrm{Li}^{+} / \mathrm{Li}$ while being compatible with metallic lithium at the negative electrode. It is worth noting that there is a significant difference between being stable over one cycle (for example linear sweep voltammetry experiments), being stable for a few hundred cycles (what most of the publications report) and for thousands of cycles (industrial requirement). One way to predict the stability of the system during cycling is by analyzing the coulombic efficiency (CE). However, the fading of CE during cycling is rarely well understood and can be attributed to many factors such as the formation of dead Li, a bad cell assembly, and also to the degradation of the electrolyte. Thus, accurately assessing the stability of the electrolyte is one of the significant parameters that must be addressed due to the critical role of the ESW in the energy density and durability of the entire ASSLB. However, if the standardization of ionic conductivity measurements starts to appear [7], ESW, while recognized as a parameter of importance, comes almost secondary when compared to ionic conductivity. Thus, it is often inconsistently reported, determined, or evaluated. 
Considering that an accurate measurement of the electrochemical stability window is a key parameter for the development of all solid-state batteries, we propose in this work a literature overview that focuses specifically on the evaluation of the electrochemical stabilities of Solid Polymer Electrolytes (SPEs) and their composites with ceramic/inorganic fillers (SCEs).

In the first part, an overview of recent articles is presented via a table regrouping several characteristics of SPEs and SCEs. This is paired with a description of traditional ways that are used by a large part of the ASSLB community to evaluate the ESW for electrolytes.

The second part is dedicated to upgraded methods and practices for a careful evaluation of ESWs. Additionally, we will present our vision on how to accurately measure the ESW of an electrolyte. The objective is to highlight the best measurement techniques to generate a better understanding and a more realistic interpretation of ESW values for SPEs and SCEs, which are expected to lead to better ASSLB stability and performance.

\section{ESW Evaluation: Overview of the Recent Literature on SPE and SCE with Typical ESW Measurements by LSV/CV Methods}

This section focuses on the ESW evaluation for SPEs and their composite counterparts with ceramic/inorganic fillers (SCE). Typically, am SPE consists of a polymer matrix with an alkali metal salt, i.e., lithium salt for ASSLB applications. In addition to the previously mentioned properties, the SPEs are expected to reduce/prevent Li dendrite formation and decrease the electrode/electrolyte interface impedance thanks to an optimal contact [8,9].

One of the most studied SPEs is polyethylene oxide (PEO), a polyether which attracted a lot of attention following the first reports describing its ionic conductivity in the presence of alkali metal salts [10-12]. Since then, PEO-based electrolytes have undergone a lot of development and several studies based on PEO and PEO derivatives have been conducted [13-16]. Throughout the years, research on non-polyether-based SPEs (alone or mixed/grafted with PEO) and composite electrolytes have been performed [16-19] to overcome limitations in the ionic conductivity and electrochemical stability of PEO. SCEs are generally prepared by the dispersion of inorganic fillers in the polymer matrix to enhance the mechanical properties, the interfacial stability/compatibility, and the ionic conductivity (by decreasing the crystallinity of the polymer host) of the solid composite electrolyte.

Table 1 groups several results including values of $\mathrm{E}_{\mathrm{ox}}$ for SPEs and SCEs (depending on the method of evaluation, temperature of the experiment, and scanning rate during the analysis) from recent articles spanning 2019-2020. It is worth noting that ESW includes stabilities in terms of oxidation $\left(\mathrm{E}_{\mathrm{ox}}\right)$ and reduction $\left(\mathrm{E}_{\text {red }}\right)$ potentials. When an additional current to the capacitive one appears, this underlines a faradic reaction (oxidation or reduction of the material/electrolyte) beyond which the system is no more stable. Some authors make the distinction between $\mathrm{E}_{\mathrm{ox}}$ and $\mathrm{E}_{\mathrm{red}}$. However, in most papers the study is only concentrated on $\mathrm{E}_{\mathrm{ox}}$ because most SPEs and SCEs are assumed to be compatible with Li metal (specifically those containing PEO). Thus, ESW is sometimes simply assimilated to $\mathrm{E}_{\mathrm{ox}}$.

Several observations can be made based on the data presented in Table 1. First, based on these recent works, we can see that PEO is still one of the most investigated polymers. However, as discussed above, polymers are now rarely used alone, but are instead blended with other polymers, copolymerized, and/or filled by ceramic/inorganic fillers (Metal Organic Frameworks (MOFs), $\mathrm{SiO}_{2}, \mathrm{BaTiO}_{3}, \mathrm{MnO}_{2}$ ). Another point is that even if some authors try to use new lithium salts, $\mathrm{LiClO}_{4}$ and LiTFSI are still the most popular salts for SPE and SCE applications. 
Table 1. Properties of various Solid Polymer-based electrolytes (PEO, other polymers and composites) from recent publications (2019-2020). The several reported properties are the ionic conductivity, the conductivity temperature evaluation, $\mathrm{E}_{\mathrm{Ox}}$ (oxidative stability of studied materials), the scanning rate for the $\mathrm{E}_{\mathrm{Ox}}$ evaluation, the temperature for ESW evaluation (RT = Room temperature) and the method used for the evaluation (cyclic voltammetry, CV; Linear sweep voltammetry, LSV).

\begin{tabular}{|c|c|c|c|c|c|c|c|c|}
\hline $\begin{array}{c}\text { Solid } \\
\text { Electrolyte/Sample }\end{array}$ & Salt & $\begin{array}{l}\text { Ionic Con- } \\
\text { ductivity } \\
(\mathrm{S} / \mathrm{cm})\end{array}$ & $\begin{array}{l}\text { Conductivity } \\
\mathrm{T}\left({ }^{\circ} \mathrm{C}\right)\end{array}$ & 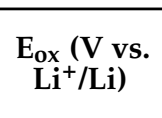 & $\begin{array}{l}\text { Scan } \\
\text { Rate } \\
(\mathrm{mV} / \mathrm{s})\end{array}$ & $\begin{array}{l}\mathrm{ESW} T \\
\left({ }^{\circ} \mathrm{C}\right)\end{array}$ & Method & References \\
\hline PCL & LiTFSI & $2.5 \times 10^{-5}$ & RT & 4.6 & 1 & 55 & LSV & [17] \\
\hline PIL-SN-PCE & LiTFSI & $6.54 \times 10^{-4}$ & RT & 5.4 & 1 & l & LSV & [18] \\
\hline DAVA + ETTMP 1300 & $\mathrm{LiPF}_{6}$ & $7.65 \times 10^{-4}$ & RT & 6 & 100 & I & LSV & [19] \\
\hline PEO8-LiPCSI & LiPCSI & $7.33 \times 10^{-5}$ & 60 & 5.53 & 0.2 & 60 & LSV & [20] \\
\hline $\begin{array}{c}\text { 3D ANF } \\
\text { framework/PEO- } \\
\text { LiTFSI }\end{array}$ & LiTFSI & $8.8 \times 10^{-5}$ & RT & $>4.5$ & 1 & / & LSV & [21] \\
\hline PEO-LiClO ${ }_{4}-\mathrm{LLZTO}$ & $\mathrm{LiClO}_{4}$ & I & 60 & 4 to 4.5 & 0.3 & I & LSV & [22] \\
\hline PEO-LiTFSI-3\%VSB-5 & LiTFSI & $4.83 \times 10^{-5}$ & 30 & 4.13 & 1 & / & LSV & [23] \\
\hline $\begin{array}{l}\text { PVA/GA with } 24 \mathrm{wt} \% \\
\text { of } \mathrm{LiClO}_{4}\end{array}$ & $\mathrm{LiClO}_{4}$ & $1.6 \times 10^{-4}$ & 25 & / & / & / & / & [24] \\
\hline $\begin{array}{l}\text { BCT (copolymer } \\
\text { dblock) }\end{array}$ & LiTFSI & $9.1 \times 10^{-6}$ & 30 & 5 & 1 & 60 & $\mathrm{CV}$ & [25] \\
\hline 5PEG-SSH & LiTFSI & $7.28 \times 10^{-6}$ & 30 & 5 & 10 & 60 & LSV & [26] \\
\hline $\begin{array}{c}\text { Li(FSI-ethyl } \\
\text { cellulose)/PEO }\end{array}$ & LiTFSI & $0.5 \times 10^{-4}$ & 70 & 4 & 10 & 70 & LSV & [27] \\
\hline Li-HCFu-PH & $\mathrm{LiPF}_{6}$ & $6.4 \times 10^{-3}$ & RT & 4.7 & 1 & RT & $\begin{array}{l}\mathrm{CV} / \\
\mathrm{LSV}\end{array}$ & [28] \\
\hline CPEG (copo EC/EO) & LiTFSI & $1.84 \times 10^{-4}$ & 30 & 4.75 & 1 & 60 & LSV & [29] \\
\hline $\begin{array}{c}\text { (PEO)-based } \\
\text { NASICON-LiZr }\left(\mathrm{PO}_{4}\right)\end{array}$ & LiTFSI & $1.2 \times 10^{-4}$ & 30 & 5 & / & / & LSV & [30] \\
\hline Dual-Li SPEs & $\begin{array}{l}\text { LiTFSI + } \\
\text { LiPVFM }\end{array}$ & $5.7 \times 10^{-4}$ & 25 & 4.5 & 5 & / & LSV & [31] \\
\hline $\begin{array}{c}\text { POSS- } \\
\text { PEGDA/PEO/LiTFSI }\end{array}$ & LiTFSI & $3.83 \times 10^{-4}$ & 60 & 5.3 & 10 & 60 & LSV & [32] \\
\hline PVT-EMIMTFSI & EMIMTFSI & $1.26 \times 10^{-4}$ & RT & 4.5 & 10 & 25 & LSV & [33] \\
\hline $\begin{array}{c}\text { PEO(LiTFSI)- } \\
\text { LLZO+PEGDME }\end{array}$ & LiTFSI & $4.7 \times 10^{-4}$ & 60 & 5.2 & 1 & 60 & LSV & [34] \\
\hline PEO-SiO ${ }_{2}$ & $\mathrm{LiClO}_{4}$ & $1.1 \times 10^{-4}$ & 30 & 5 & 1 & l & LSV & [35] \\
\hline $\mathrm{PEO} / \mathrm{MnO}_{2}$ & LiTFSI & $1.95 \times 10^{-5}$ & 30 & 4.5 & 1 & 60 & LSV & [36] \\
\hline SIGPE & LiSTFSI & $0.84 \times 10^{-3}$ & RT & 5.2 & 1 & RT & LSV & [37] \\
\hline $\begin{array}{l}\text { 8-PEG-MALC, 8-PEG, } \\
\text { PEGDA }\end{array}$ & LiTFSI & $6.2 \times 10^{-5}$ & RT & 4.5 & 1 & RT & LSV & [38] \\
\hline PEO/Al-MOF 5\% & LiTFSI & $2.09 \times 10^{-5}$ & 30 & 4.7 & 5 & 30 & LSV & [39] \\
\hline PEO/MOF-UIO66 & LiTFSI & $1.47 \times 10^{-4}$ & 30 & 5.2 & 0.5 & / & LSV & [40] \\
\hline $\begin{array}{c}\mathrm{PEO} / \mathrm{PVDF} / \mathrm{LiClO}_{4} / \\
\mathrm{TiO}_{2} / \mathrm{PC}\end{array}$ & $\mathrm{LiClO}_{4}$ & $10.2 \times 10^{-6}$ & 27 & 3 & / & RT & LSV & [41] \\
\hline $\begin{array}{l}\text { polycarbonates/polyethers } \\
\text { with linear and cyclic } \\
\text { carbonates linkages }\end{array}$ & s LiTFSI & $5.6 \times 10^{-5}$ & 25 & 5.6 & 0.5 & 70 & $\mathrm{CV}$ & [42] \\
\hline LiTFPFB/P(PO/EM) & LiTFPFB & $1.55 \times 10^{-4}$ & 70 & 4.6 & 5 & 70 & LSV & [43] \\
\hline CPE-(SiO $\left.{ }_{2} @ P M M A\right)$ & LiTFSI & $8.54 \times 10^{-5}$ & 60 & 4.7 & 0.5 & / & LSV & [44] \\
\hline $\begin{array}{l}\text { PEO/LDH (layer } \\
\text { double hydroxide) }\end{array}$ & LiTFSI & $1.1 \times 10^{-5}$ & 30 & 5 & 0.5 & / & LSV & [45] \\
\hline
\end{tabular}


Table 1. Cont.

\begin{tabular}{|c|c|c|c|c|c|c|c|c|}
\hline $\begin{array}{c}\text { Solid } \\
\text { Electrolyte/Sample }\end{array}$ & Salt & $\begin{array}{l}\text { Ionic Con- } \\
\text { ductivity } \\
\text { (S/cm) }\end{array}$ & $\begin{array}{c}\text { Conductivity } \\
\mathrm{T}\left({ }^{\circ} \mathrm{C}\right)\end{array}$ & $\begin{array}{c}\mathrm{E}_{\mathbf{0 x}}(\mathrm{V} \text { vs. } \\
\left.\mathrm{Li}^{+} / \mathrm{Li}\right)\end{array}$ & $\begin{array}{l}\text { Scan } \\
\text { Rate } \\
(\mathrm{mV} / \mathrm{s})\end{array}$ & $\underset{\left({ }^{\circ} \mathrm{C}\right)}{\text { ESW T }}$ & Method & References \\
\hline $\begin{array}{l}\text { CSE (PEO-LiClO } 4^{-} \\
\text {PVDF / Al-LLZO) }\end{array}$ & $\mathrm{LiClO}_{4}$ & $1.73 \times 10^{-4}$ & 70 & 5.25 & 2 & 70 & LSV & [46] \\
\hline PVDF-HFP-LLZO & LiTFSI & $1.12 \times 10^{-3}$ & 30 & 4.6 to 4.9 & 1 & / & LSV & [47] \\
\hline $\begin{array}{l}\text { LAGP-PEO } \\
\text { LAGP-PEA } \\
\text { LAGP-epoxy }\end{array}$ & $\begin{array}{l}\text { LiTFSI and } \\
\mathrm{LiCLO}_{4}\end{array}$ & $\begin{array}{l}1.25 \times 10^{-4} \\
7.4 \times 10^{-4} \\
8.4 \times 10^{-4}\end{array}$ & $\begin{array}{l}25 \\
25 \\
25\end{array}$ & 4.5 & 0.1 & / & $\mathrm{CV}$ & [48] \\
\hline $\begin{array}{l}\text { CS(chitosan)-LiTFSI- } \\
\text { PEO }\end{array}$ & LiTFSI & $6.8 \times 10^{-4}$ & RT & 5 & 5 & / & LSV & [49] \\
\hline $\begin{array}{c}\text { LLTO-PAN- } \\
\text { SN(succinonitrile) }\end{array}$ & LiTFSI & $2.2 \times 10^{-3}$ & 30 & 5.1 & 1 & 25 & LSV & {$[50]$} \\
\hline LSZP-PVDF & LiTFSI & $5.76 \times 10^{-5}$ & 25 & 4.73 & 0.2 & RT & LSV & [51] \\
\hline $\mathrm{P}(\mathrm{EGDMA}-\mathrm{DODT})$ & LiTFSI & $2.7 \times 10^{-5}$ & RT & 4.3 & / & 25 & $\mathrm{CV}$ & [52] \\
\hline $\mathrm{PVDF} / \mathrm{PEO} / \mathrm{LiClO}_{4}$ & $\mathrm{LiClO}_{4}$ & $2.01 \times 10^{-5}$ & 27 & 3 & 50 & RT & LSV & {$[53]$} \\
\hline $\begin{array}{c}\text { poly(ethylene oxide } \\
\text { carbonate) }\end{array}$ & LiTFSI & $1.2 \times 10^{-4}$ & 70 & 4.9 & 0.5 & 70 & LSV & {$[54]$} \\
\hline $\begin{array}{l}\text { HCPE (derived PEG } \\
\text { SPE) }\end{array}$ & LiTFSI & $5.62 \times 10^{-5}$ & RT & 5.28 & 10 & 25 & LSV & [55] \\
\hline $\begin{array}{l}\text { poly (PEGDA-PEMP- } \\
\text { PDMS) }\end{array}$ & LiTFSI & $1.08 \times 10^{-5}$ & 25 & 5 & 1 & 60 & LSV & [56] \\
\hline $\begin{array}{c}\text { Cross-linked } \\
\text { nanoparticle-polymer } \\
\text { composites (CNPCs) } \\
\text { OH-PEO-SiO } 2 \\
\end{array}$ & LiTFSI & $3 \times 10^{-3}$ & 25 & 5 & 1 & RT & $\mathrm{LSV} / \mathrm{CV}$ & [57] \\
\hline PEO-LATP & LiTFSI & $1.15 \times 10^{-5}$ & 30 & 5 & I & 30 & $\mathrm{CV} / \mathrm{LSV}$ & {$[58]$} \\
\hline $\begin{array}{l}\text { PVAc in P(VdF-HFP)- } \\
\text { LiTFSI-EC }\end{array}$ & LiTFSI & $1.1 \times 10^{-3}$ & RT & 4.7 & 0.5 & RT & LSV & [59] \\
\hline $\begin{array}{l}\text { poly(PEGDGE-PEMP- } \\
\text { PDMS) }\end{array}$ & LiTFSI & $1.5 \times 10^{-6}$ & RT & 5.3 & 0.1 & 60 & $\mathrm{CV}$ & {$[60]$} \\
\hline $\begin{array}{l}\text { PEG250-POSS- } \\
\text { 4PEG2k }\end{array}$ & LiTFSI & $3 \times 10^{-4}$ & $\mathrm{RT}$ & 4 & / & 90 & $\mathrm{CV}$ & [61] \\
\hline $\mathrm{PEO} / \mathrm{LAGP}$ & LiTFSI & $1.6 \times 10^{-5}$ & 20 & 4.5 & 0.1 & 60 & $\mathrm{CV}$ & {$[62]$} \\
\hline LLTO(NF)/PEO & $\mathrm{LiClO}_{4}$ & $4.01 \times 10^{-4}$ & 60 & 5.1 & 1 & 60 & LSV & {$[63]$} \\
\hline PEO34-PC $10 w t \%$ MA & LiTFSI & $1.3 \times 10^{-3}$ & 70 & 4.9 & 0.5 & 70 & $\mathrm{CV}$ & {$[64]$} \\
\hline $\begin{array}{l}\text { P(SSPSILi-alt- } \\
\text { MA)/PEO }\end{array}$ & SSPSILi & $3.08 \times 10^{-4}$ & 25 & 5 & 10 & 80 & LSV & [65] \\
\hline $\begin{array}{l}\text { HSPE(polysiloxane/ } \\
\text { polyetherdiamine) }\end{array}$ & $\mathrm{LiClO}_{4}$ & $5.8 \times 10^{-4}$ & 80 & 4.8 & 1 & / & LSV & [66] \\
\hline Grafted polyrotaxane & LiTFSI & $1 \times 10^{-4}$ & RT & 4.7 & 0.05 & 60 & LSV & [67] \\
\hline $\begin{array}{l}\mathrm{NOE} / \mathrm{PEO} \text { and } \\
\mathrm{LSA} / \mathrm{PEO}\end{array}$ & LiTFSI & $5.08 \times 10^{-5}$ & RT & 4.2 & 10 & / & $\mathrm{CV}$ & [68] \\
\hline PEO-CuO fillers & LiTFSI & $1 \times 10^{-4}$ & 30 & 4.8 & 1 & 25 & LSV & {$[69]$} \\
\hline $\begin{array}{l}\text { bis(2-methoxyethyl) } \\
\text { ether (diglyme) }\end{array}$ & $\mathrm{LiNO}_{3}$ & / & / & 4.5 & 10 & RT & LSV & [70] \\
\hline $\mathrm{PEO}-\mathrm{BaTiO}_{3}$ & LiTFSI & $\begin{array}{l}1.8 \times 10^{-5} \\
1.6 \times 10^{-3} \\
\end{array}$ & $\begin{array}{l}25 \\
80\end{array}$ & 4.7 & 0.5 & 80 & LSV & [71] \\
\hline PEGDGE & $\begin{array}{l}\text { LiTFSI } \\
\mathrm{LiBF}_{4}\end{array}$ & $0.11 \times 10^{-3}$ & RT & 5.5 & 0.1 & 60 & $\mathrm{LSV} / \mathrm{CV}$ & [72] \\
\hline PEO/TDI/PEG & LiTFSI & $0.17 \times 10^{-3}$ & 60 & 5 & 0.5 & 60 & $\mathrm{LSV} / \mathrm{CV}$ & [73] \\
\hline PIL-LiTFSI-LATP & LiTFSI & $7.78 \times 10^{-5}$ & 30 & 4.5 & 5 & 60 & LSV & [74] \\
\hline
\end{tabular}


Table 1. Cont.

\begin{tabular}{|c|c|c|c|c|c|c|c|c|}
\hline $\begin{array}{c}\text { Solid } \\
\text { Electrolyte/Sample }\end{array}$ & Salt & $\begin{array}{l}\text { Ionic Con- } \\
\text { ductivity } \\
(\mathrm{S} / \mathrm{cm})\end{array}$ & $\begin{array}{c}\text { Conductivity } \\
\text { T }\left({ }^{\circ} \mathrm{C}\right)\end{array}$ & $\begin{array}{c}\mathrm{E}_{\mathbf{o x}}(\mathrm{V} \text { vs. } \\
\left.\mathrm{Li}^{+} / \mathrm{Li}\right)\end{array}$ & $\begin{array}{l}\text { Scan } \\
\text { Rate } \\
(\mathrm{mV} / \mathrm{s})\end{array}$ & $\underset{\left({ }^{\circ} \mathrm{C}\right)}{\text { ESW T }}$ & Method & References \\
\hline $\begin{array}{l}\text { Anion-regulated } \\
\text { PEGPEA-SiO }_{2}\end{array}$ & LiTFSI & $2.16 \times 10^{-5}$ & RT & 4.8 & 0.1 & 55 & $\mathrm{CV}$ & [75] \\
\hline PEO@GF & LiTFSI & $1.9 \times 10^{-4}$ & 60 & 4.9 & 0.1 & / & LSV & [76] \\
\hline UV-PCCE & LiTFSI & $0.91 \times 10^{-3}$ & RT & 4.78 & 0.1 & 25 & $\mathrm{CV} / \mathrm{LSV}$ & [77] \\
\hline (PTHF)-based SPE & $\mathrm{LiClO}_{4}$ & $2.3 \times 10^{-4}$ & 60 & 4.5 & 1 & 60 & $\mathrm{CV}$ & [78] \\
\hline $\begin{array}{l}\text { HGO(holey graphene } \\
\text { oxide)-PEO }\end{array}$ & LiTFSI & $6.05 \times 10^{-4}$ & 60 & 5.2 & 5 & / & LSV & [79] \\
\hline $\begin{array}{c}\text { PEO:LiTFSI:SN } \\
(15 \%): L A O(10 \%)\end{array}$ & LiTFSI & $1.36 \times 10^{-5}$ & 30 & 5.2 & 10 & 60 & LSV & [80] \\
\hline PEO-LLZTO-MMT & LiTFSI & $4.7 \times 10^{-3}$ & 70 & 4.6 & 10 & / & LSV & [81] \\
\hline $\begin{array}{c}\text { cross-linked-PEO- } \\
\text { TEGDME-TEGDMA }\end{array}$ & LiTFSI & $2.7 \times 10^{-4}$ & 24 & 5.38 & 0.1 & 25 & CV/LSV & [82] \\
\hline 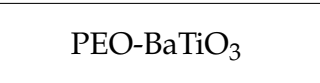 & LiTFSI & $\begin{array}{l}2.2 \times 10^{-5} \\
1.9 \times 10^{-3}\end{array}$ & $\begin{array}{l}25 \\
80\end{array}$ & 5 & 0.5 & 80 & LSV & [83] \\
\hline PVA, PMP-TFSI & LiTFSI & $3 \times 10^{-3}$ & 60 & 4.6 & 0.5 & / & LSV & [84] \\
\hline NH2-PEG-NH2 & $\begin{array}{l}\mathrm{LiClO}_{4}, \\
\mathrm{LiTFSI} \\
\mathrm{LiBF}_{4}\end{array}$ & $1.9 \times 10^{-4}$ & RT & 5 & 0.1 & / & LSV & [85] \\
\hline $\begin{array}{c}\text { PEO grafted } \\
\text { polyimide (PI-g-PEO) }\end{array}$ & LiTFSI & $1 \times 10^{-4}$ & 40 & 5 & 0.1 & 60 & $\mathrm{CV} / \mathrm{LSV}$ & [86] \\
\hline $\begin{array}{l}\text { LLZN NWs filled } \\
\text { PMMA-LiClO }_{4}\end{array}$ & $\mathrm{LiClO}_{4}$ & $2.2 \times 10^{-5}$ & RT & 4.7 & 1 & 60 & LSV & [87] \\
\hline $\begin{array}{l}\text { Halloysite nanotubes } \\
\text { (HNTs)-PEO }\end{array}$ & LiTFSI & $9.23 \times 10^{-5}$ & 25 & 5.14 & 10 & 25 & LSV & [88] \\
\hline $\begin{array}{c}\text { PVDF- } \\
\mathrm{HFP} / \mathrm{PEO} / \mathrm{LAGP}\end{array}$ & LiFSI & $3.27 \times 10^{-3}$ & RT & 4.9 & 1 & / & LSV & [89] \\
\hline POSS-PEG-PIL & LiTFSI & $\begin{array}{l}1.86 \times 10^{-5} \\
2.07 \times 10^{-4}\end{array}$ & $\begin{array}{l}25 \\
60 \\
\end{array}$ & 4.7 & 1 & 90 & LSV & [90] \\
\hline $\begin{array}{l}\text { vertically aligned } \\
\text { LAGP- PEO }\end{array}$ & LiTFSI & $1.67 \times 10^{-4}$ & $\mathrm{RT}$ & 4.5 & 5 & 60 & $\mathrm{CV}$ & [91] \\
\hline $\begin{array}{c}\text { PVDF- } \\
\text { HFP/LiTFSI/LLZO }\end{array}$ & LiTFSI & $9.5 \times 10^{-4}$ & RT & 5.2 & 0.1 & RT & LSV & [92] \\
\hline PIL-PEO & LiTFSI & $6.12 \times 10^{-4}$ & 55 & 5.44 & 1 & 55 & LSV & [93] \\
\hline LLZO-PVDF & $\mathrm{LiClO}_{4}$ & $2.6 \times 10^{-4}$ & 25 & 4.8 & 1 & 25 & LSV & [94] \\
\hline PVA-Upy-PEG750 & $\mathrm{LiClO}_{4}$ & $1.51 \times 10^{-4}$ & 60 & 5 & 0.1 & $\mathrm{RT}$ & LSV & [95] \\
\hline PS-PEG-PS & LiTFSI & $1.1 \times 10^{-3}$ & 70 & 4.5 & 0.1 & 70 & $\mathrm{CV} / \mathrm{LSV}$ & [96] \\
\hline (PEO) K-SPE750-Li & $\mathrm{LiClO}_{4}$ & $2.82 \times 10^{-5}$ & 20 & $\begin{array}{l}5.4 \\
5.3\end{array}$ & 0.1 & $\begin{array}{l}60 \\
25\end{array}$ & $\begin{array}{l}\text { LSV } \\
\text { LSV }\end{array}$ & [97] \\
\hline LiFPFSI/PEO & LiFPFSI & $6.2 \times 10^{-4}$ & 80 & 5.6 & 0.5 & 80 & LSV & [16] \\
\hline $\begin{array}{l}\text { sPS-LiTFSI/PEGDA/ } \\
\text { succinonitrile }\end{array}$ & LiTFSI & $0.43 \times 10^{-3}$ & RT & $5-5.3$ & 0.5 & / & $\mathrm{LSV} / \mathrm{CV}$ & [98] \\
\hline PGO & $\mathrm{LiClO}_{4}$ & $2.08 \times 10^{-5}$ & 50 & 4.4 & 1 & RT & LSV & [99] \\
\hline $\begin{array}{l}\text { PPC-PEO } 10 \mathrm{~W} \\
\text { [5:5]-1\%wt LAGP }\end{array}$ & LiTFSI & $8.39 \times 10^{-4}$ & 60 & 4.5 & 0.5 & 60 & LSV & [100] \\
\hline PVDF/PVAC-LLZTO & $\mathrm{LiClO} 4$ & $4.8 \times 10^{-4}$ & RT & 4.85 & 0.1 & I & LSV & [101] \\
\hline PEO-N1222FSI-LiFSI & LiFSI & $2.14 \times 10^{-4}$ & 50 & 5 & 1 & 50 & LSV & [102] \\
\hline Li-Nafion/LLZAO & I & $2.26 \times 10^{-4}$ & 30 & 4.8 & 0.1 & 30 & $\mathrm{CV} / \mathrm{LSV}$ & [103] \\
\hline
\end{tabular}


Table 1. Cont.

\begin{tabular}{|c|c|c|c|c|c|c|c|c|}
\hline $\begin{array}{c}\text { Solid } \\
\text { Electrolyte/Sample }\end{array}$ & Salt & $\begin{array}{l}\text { Ionic Con- } \\
\text { ductivity } \\
(\mathrm{S} / \mathrm{cm})\end{array}$ & $\begin{array}{l}\text { Conductivity } \\
\text { T }\left({ }^{\circ} \mathrm{C}\right)\end{array}$ & $\underset{\left.\mathrm{Li}^{+} / \mathrm{Li}\right)}{\mathrm{E}_{\mathrm{ox}}(\mathrm{V} \mathbf{v s} .}$ & $\begin{array}{l}\text { Scan } \\
\text { Rate } \\
(\mathrm{mV} / \mathrm{s})\end{array}$ & $\begin{array}{c}\text { ESW T } \\
\left({ }^{\circ} \mathrm{C}\right)\end{array}$ & Method & References \\
\hline $\begin{array}{c}\text { PPO-PEO-PPO/HO- } \\
\text { PEO-SiO } \\
\end{array}$ & $\mathrm{LiPF}_{6} / \mathrm{LiTFSI}$ & $1.32 \times 10^{-3}$ & 20 & 6.5 & 1 & 20 & $\mathrm{CV}$ & [104] \\
\hline $\begin{array}{c}\text { Sandwich-type } \\
\text { PVDF-HFP-LLZTO }\end{array}$ & LiTFSI & $2.29 \times 10^{-4}$ & 30 & 5.3 & 1 & 40 & LSV & [105] \\
\hline LLZTO/PEO-LiTFSI & LiTFSI & $2.61 \times 10^{-4}$ & 25 & 6 & 1 & / & LSV & [106] \\
\hline PEO-ta-POSS & LiTFSI & $1.2 \times 10^{-3}$ & 90 & 3.8 & 0.2 & I & $\mathrm{CV}$ & [107] \\
\hline g-C3N4/PEO (CSPE) & LiTFSI & $1.7 \times 10^{-5}$ & 30 & 4.7 & 5 & 60 & LSV & [108] \\
\hline N1222FSI-PIL & LiTFSI & $2.08 \times 10^{-4}$ & 25 & 5 & 1 & 40 & LSV & [109] \\
\hline hbPPEGMAm-s-PSn & LiTFSI & $9.5 \times 10^{-5}$ & 60 & 4.3 & 0.2 & / & LSV & [110] \\
\hline PEO-cPTFBC & LiDFOB & $2.2 \times 10^{-5}$ & 50 & 4.7 & 1 & 60 & LSV & [111] \\
\hline $\mathrm{PEO} @ \mathrm{SiO}_{2}$ & $\mathrm{LiClO}_{4}$ & $1.1 \times 10^{-4}$ & 30 & 4.8 & 10 & 90 & LSV & [112] \\
\hline LLZTO/PEO & LiTFSI & $1.31 \times 10^{-5}$ & 25 & 5.2 & 1 & RT & LSV & [113] \\
\hline
\end{tabular}

This overview of SPEs and SCEs based on recent literature allows us to evidence not only the variety of the tested systems but also of the experimental parameters (method, scanning rate, temperature) for the ESW evaluation of the solid polymer and composite electrolytes. Also, upon scanning the literature, the ESW is recognized as a parameter of importance but appears to come almost secondary in comparison to ionic conductivity. Consequently, the accurate evaluation of the electrochemical stability (ESW) of the electrolytes is often briefly addressed in most papers.

ESW is usually evaluated by the Linear Sweep Voltammetry (LSV) method in a lithium/electrolyte/inert planar electrode ( $\mathrm{Pt}$, Stainless steel) cell configuration. Inert working electrodes are used to avoid parasitic reactions and interfering current backgrounds (Figures 2 and 3). Typically, the current at a working electrode is measured while the potential is swept linearly vs. time from lower to higher potentials.

The objective is to detect at which potential the SPE or the SCE will be oxidized/reduced and, thus, degraded. Basically, when LSV is applied, after the capacitive current associated with the electrochemical double layer (which appears as soon as the potential of the electrode is changed), the oxidation (faradic current) is determined when a sudden increase of the current appears at a given potential. Figure 4 shows an example of an experimental LSV profile. Depending on the authors, experimental parameters such as temperature evaluation, scanning rate, determination of the potential estimated as the beginning of the oxidation ( $4.7 \mathrm{~V}$ in this example), or the minimum current value considered as a realistic value meaning that oxidation occurs, are quite different. We need to keep in mind the non-ideal conditions when performing ESW assessment for SPEs or SCEs. An analogy with liquid electrolytes can be demonstrated. In liquid electrolytes, new species diffuse from the bulk towards the electrode. New oxidizable species will diffuse and it will become complicated to get practical limiting current values. Now for the polymeric systems, another limitation appears. Indeed, they do not diffuse, or hardly diffuse, which means no renewal of the oxidizable species is possible. This places emphasis on the amount of SPEs initially in contact with the electrode. These limitations lead to the necessity of having a large analysis area for the ESW determination of SPEs and SCEs. Thus, it is hard to point out precise values and a standard ESW evaluation method. 

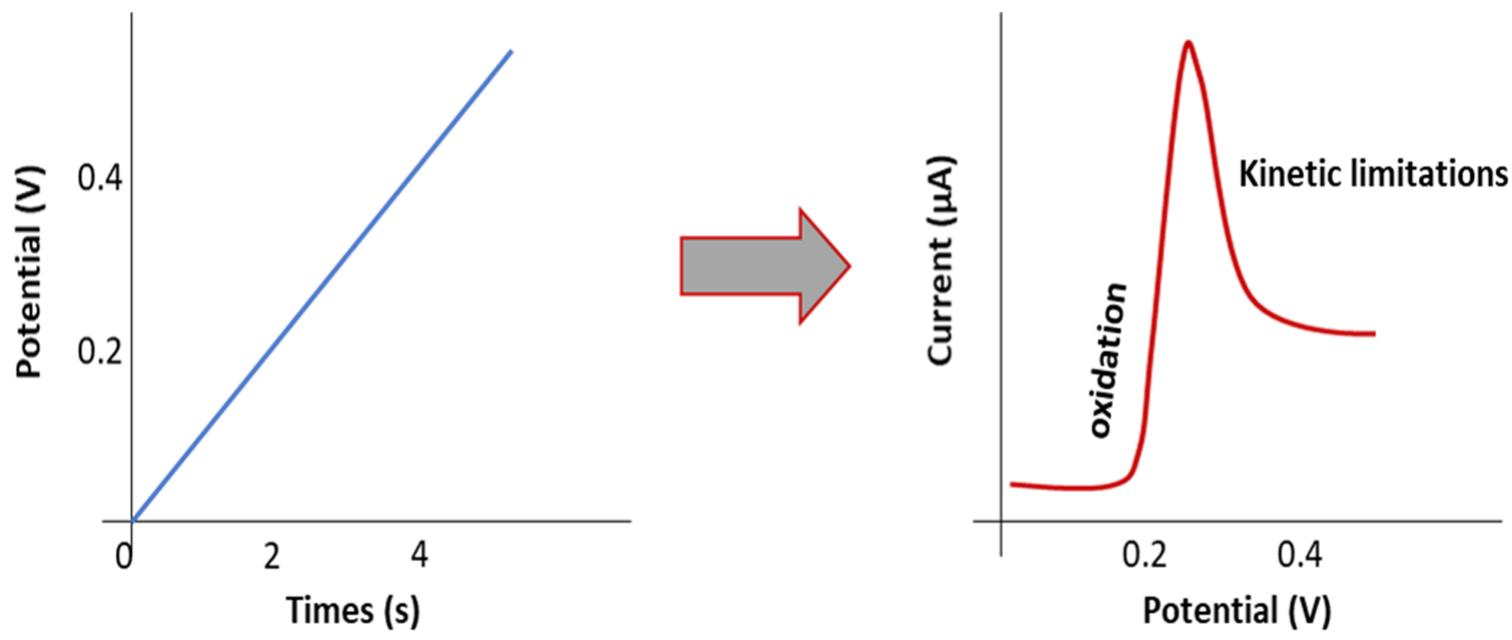

Figure 2. Scheme representing the principle of the LSV method.
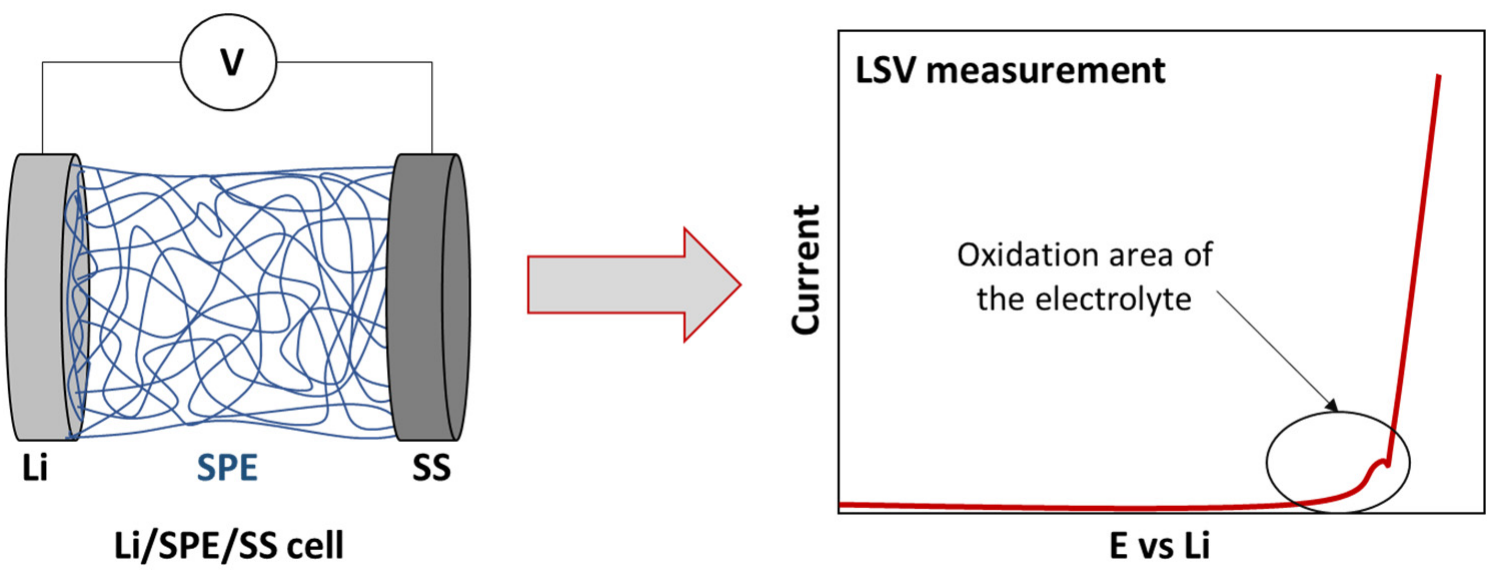

E vs Li

Figure 3. Scheme of traditional cell for ESW evaluation by LSV measurement.

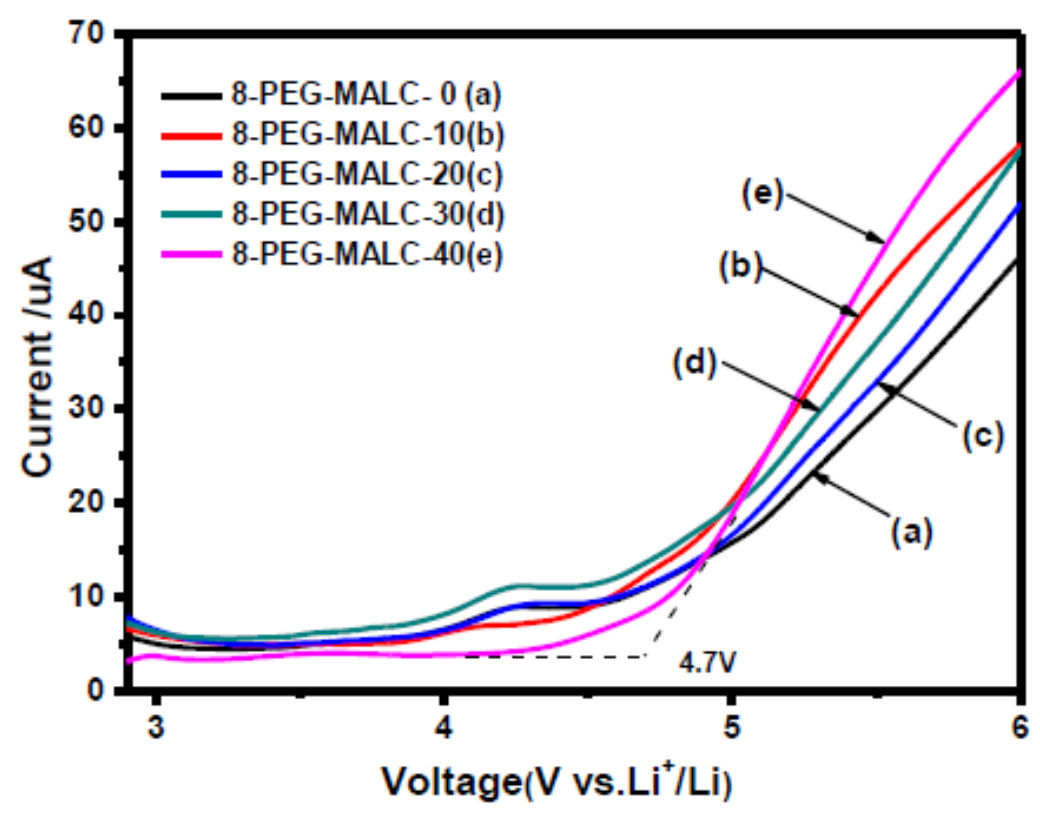

Figure 4. Linear sweep voltammetry of different liquid crystalline copolymer composite polymer electrolytes at $0.1 \mathrm{mV} / \mathrm{s}$ with a cut-off limit evaluated at $4.7 \mathrm{~V}$; extract from ref. [38]. 
Cyclic voltammetry is the second most frequently used method for evaluating the ESW of SPEs or SCEs. In a typical experiment, the working electrode potential is ramped linearly versus time from the open circuit voltage to a set potential. After the set potential is reached, the working electrode's potential is ramped back in the opposite direction to the initial potential. These cycles of potential sweeps can be repeated as many times as needed (Figure $5 b, c$ ). However, it is important to keep in mind that once the first oxidation is initiated, it is likely that during the other cycles the material has been altered due to this first oxidation. The current at the working electrode is plotted versus the applied voltage to give the cyclic voltammogram. Oxidation (positive current) and reduction (negative current) peaks can be observed if redox species react at the surface of the working electrode. These reactions can be related to the stability of the species. Especially, when analyzing electrolyte solutions and naturally for solid electrolytes such as SPEs or SCEs, the appearance of intense redox peaks at a given potential is characteristic of the occurrence of a reaction which can be related to electrolyte degradation. It is important to note that two different cells must be used for the evaluation of the anodic and the cathodic stability of the electrolyte even if some authors still use the same cell for both analyses. For instance, in their work, Piana et al. [62] made the choice to evaluate the SCE (PEO/LAGP hybrid electrolyte) by scanning the cell potential from the OCV (open circuit potential) down toward $-0.3 \mathrm{vs} . \mathrm{Li}^{+} / \mathrm{Li}$ and, then, upward to $2.5 \mathrm{~V} \mathrm{vs.} \mathrm{Li}^{+} / \mathrm{Li}$ (cathodic stability window) in a $\mathrm{Li} / \mathrm{SCE} / \mathrm{Cu}$ cell configuration, and from the OCV toward $5.0 \mathrm{~V} \mathrm{vs.} \mathrm{Li}^{+} / \mathrm{Li}$ and, then, downward to $2.5 \mathrm{~V} \mathrm{vs.} \mathrm{Li}^{+} / \mathrm{Li}$ (anodic stability window) in a $\mathrm{Li} / \mathrm{SCE} /$ Carbon black cell configuration with a scanning rate of $0.1 \mathrm{mV} / \mathrm{s}$. In that case, both cells use planar working electrodes ( $\mathrm{Cu}$ and carbon black coated $\mathrm{Al}$ foil) for the ESW evaluation. Thus, the stability of the SPEs and SCEs can be analyzed via CV in a similar way to with LSV. The cell configuration is often identical to the one for LSV analysis and, once again, a huge range of choices about the setup of parameters like temperature and scanning rates is also observed. For instance, Figure 6 shows the distribution of scanning rates used for ESW evaluation by LSV/CV taken from Table 1. A clear trend towards low and moderate scanning rates $(0.1$ to $1 \mathrm{mV} / \mathrm{s}$ ) is observed. However, many other authors use higher scanning rates ( $>5 \mathrm{mV} / \mathrm{s}$ ). It must also be noted that even $1 \mathrm{mV} / \mathrm{s}$ can be considered to be a high scanning rate for ESW evaluations because of the sluggish processes involved in the degradation of solid-state electrolytes.

Thus, it is hard to conclude how representative these tests are of the true ESW. No strict rules are established for evaluating the ESW, even if low scanning rates seem like they would be beneficial, and it is difficult to get a satisfying conclusion about the realistic impact of these values [114]. Other factors such as how long the system experiences the potential, the analysis volume, and the non-mobility of the polymer (for SPE) must be addressed. Nevertheless, this methodology has changed little over time [115-118]. 
a)

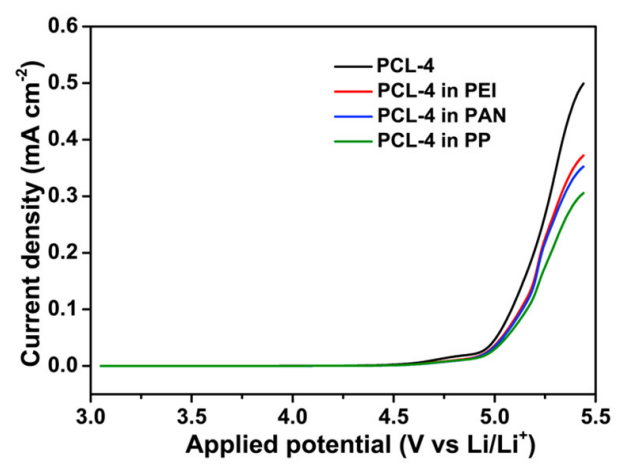

b)

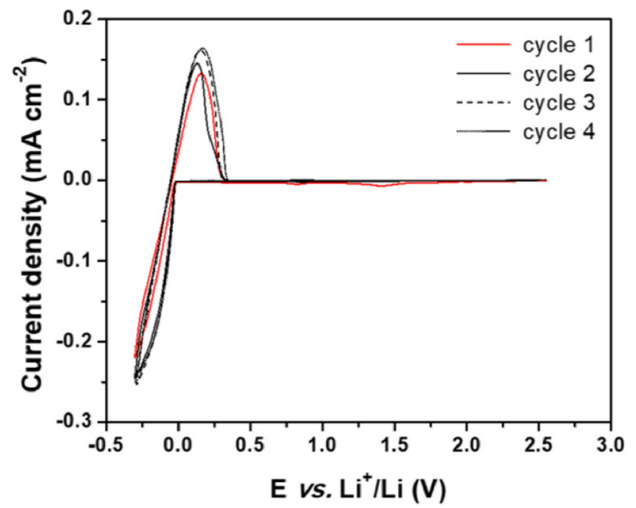

c)

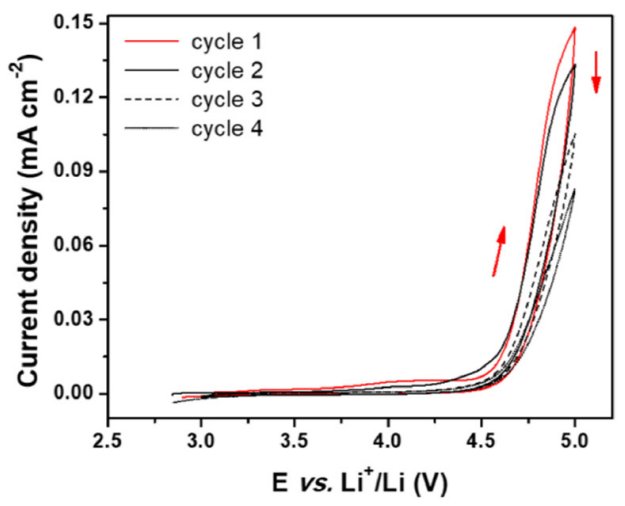

Figure 5. (a) Example of LSV profiles at $1 \mathrm{mV} / \mathrm{s}$ and $55^{\circ} \mathrm{C}$. Extracted with permission from ref. [17]. Copyright 2020 Elsevier. (b) and (c) CV profiles at $60{ }^{\circ} \mathrm{C}$ and a scanning rate of $0.1 \mathrm{mV} / \mathrm{s}$; (b) cathodic stability highlighting the Lithium oxidation/reduction at low potentials (cell configuration: $\mathrm{Li} / \mathrm{SCE} / \mathrm{Cu}$ ); and (c) anodic stability highlighting the oxidation of the electrolyte at high potentials (cell configuration: Li/SCE/Carbon black). Extracted with permission from ref. [62]. Copyright 2019 Elsevier.

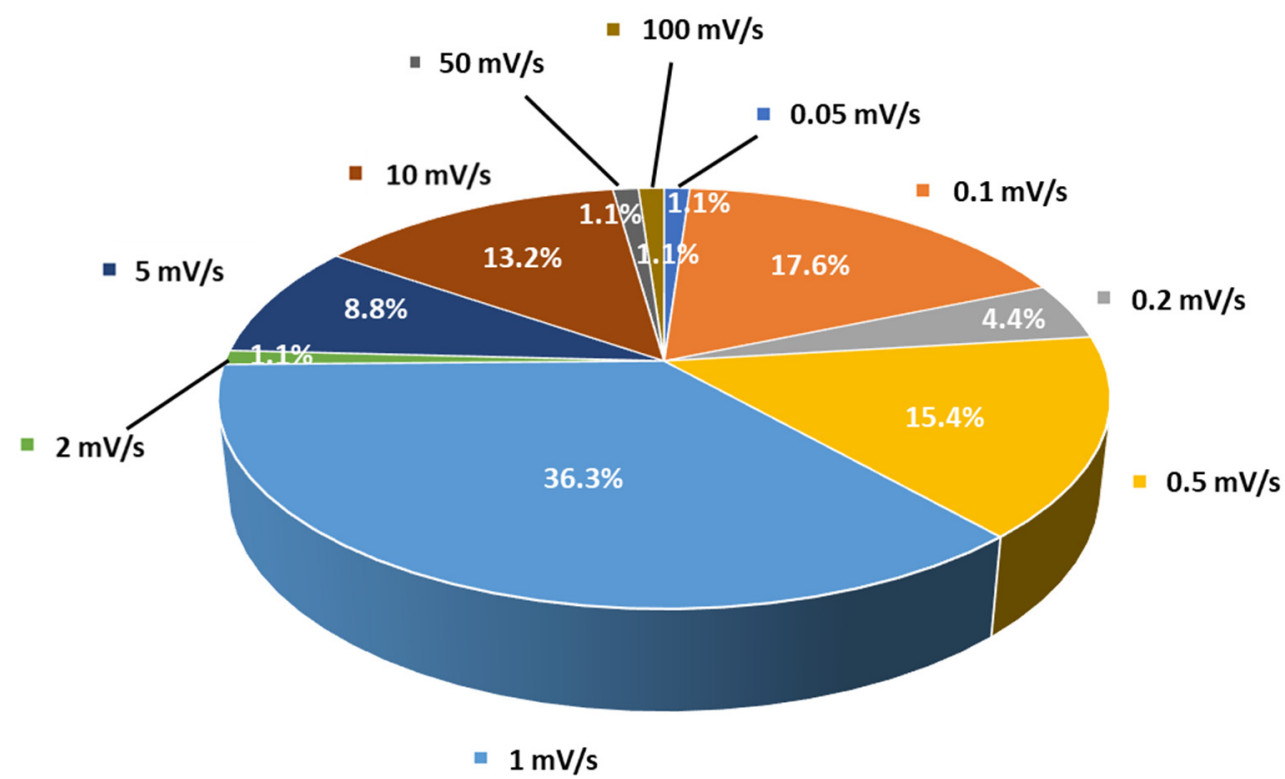

Figure 6. Distribution of scanning rates (\%) used by authors for ESW evaluations taken from Table 1. 


\section{Toward a More Specific and Better Evaluation of the ESW}

For ASSLB, the use of solid electrolytes requires them to be stable at high potentials vs $\mathrm{Li}^{+} / \mathrm{Li}$ and compatible with high voltage cathode materials (NMC, NCA) operating up to $4.2 / 4.3 \mathrm{~V}[96,119,120]$ while remaining compatible with the lithium metal anode. Surprisingly, despite high oxidation limits claimed in most publications (largely above $4.0 \mathrm{~V} \mathrm{vs} . \mathrm{Li}^{+} / \mathrm{Li}$ ), the electrochemical characterization of these materials in a battery set up is usually performed using LFP cathodes, which have a redox potential of $3.45 \mathrm{Vvs}$. $\mathrm{Li}^{+} / \mathrm{Li}$. The fact that the well-known cathode material NMC, which has a potential window of 3.0-4.3 $\mathrm{V} \mathrm{vs.} \mathrm{Li}^{+} / \mathrm{Li}$, is not used in these publications to further qualify the stability of their electrolyte leads to questions regarding the validity of the ESW measurement.

The purpose of this section is to highlight articles that are specifically dedicated to the evaluation of the ESW of electrolytes. This chapter is focused on describing "advanced" methods to accurately evaluate the ESW of SPEs and SCEs. Some papers on Inorganic Solid Electrolytes (ISE) or liquid electrolytes are also addressed in this part when an interesting approach to the ESW evaluation is conducted and that can be adapted for use in systems employing SPEs and SCEs.

Even if it is barely addressed, some authors try to improve the evaluation of the electrochemical stability of the electrolytes. Two main characteristics arise regarding a suitable evaluation of the ESW: the cell construction and the optimization of the experimental setup generally based on the techniques previously described (LSV and CV).

The architecture and the configuration of the electrochemical cell for ESW determination is indeed an important parameter. Although standard cells consist of three-electrodes (working electrode, counter electrode and reference electrode), most of the measurements, for convenience, (specifically for battery applications) are made in a two-electrode cell configuration (with one electrode playing the role of both reference and counter electrode). Most of the studies use metallic lithium as both reference and counter electrode assuming that the SPE or SCE materials are stable vs. lithium or indium-lithium alloys and stainless steel as a working electrode. Sometimes these experimental considerations vary (different electrode materials) and strongly impact the value of the ESW. These considerations will be discussed in detail in the next section.

\subsection{Cell Configuration}

As was mentioned previously, the standard cell configuration for the evaluation of the ESW is a Lithium/electrolyte/stainless steel (SS) cell (Figure 3). Sometimes, variations, such as the use of other inert planar electrodes, can be observed. For instance, Piana et al. [62] used $\mathrm{Cu}$ metal foil and carbon black coated $\mathrm{Al}$ foil as working electrodes for cathodic and anodic scans, respectively, with Li metal as both the counter and the reference electrodes. However, some authors who have focused on characterizing suitable ESW evaluation insist on the importance of the cell configuration and especially on the suppression of the inert planar electrode. Indeed, their geometric surface area and chemical composition is negligible compared to that of the composite electrodes that are used in practical battery devices and, thus, disregard the real electrochemical environment of the evaluated electrolytes. This often results to an overestimation and inappropriate ESW values.

In their work (1999) Xu et al. [121] recommended that to achieve a real electrochemical stability window (for capacitor and battery applications), the electrode material used for the ESW evaluation should simulate the electrodes used in a real system. The electrolyte stability data generated by conventional approaches (cf. Section 1) could be inaccurate when applied to electrolytes in real devices. Although this work dealt with liquid electrolytes, it is reasonable to assume that these ideas could be extended to solid electrolytes (i.e., with SPEs and SCEs). Some experimental details of their work are presented here. First, the electrolytes, electrode materials, and subsequent measurements were all handled under vacuum in an argon-filled glove box where both $\mathrm{H}_{2} \mathrm{O}$ and $\mathrm{O}_{2}$ content was below $5 \mathrm{ppm}$. Solvents of electrolytes were redistilled and well dried until the moisture content 
decreased below 100 ppm (around 50 ppm as determined according to the Karl Fischer titration method).

Linear or cyclic voltammetry were used for measuring the current-potential (i-V) polarization curves of the tested electrolytes. The three-electrode cell configuration was employed with either Pt wire, glassy carbon (GC), activated carbon (AC) film or lithium battery cathode composite $\mathrm{Li}_{x} \mathrm{Mn}_{2} \mathrm{O}_{4}$ as working electrodes, and with $\mathrm{Li}^{+} / \mathrm{Li}$ as the reference electrode. Lithium foil was used as the counter electrode for lithium battery tests. A scan rate of $5.0 \mathrm{mV} / \mathrm{s}$ was typically used, except for cathode composite where the measurement was performed at $0.1 \mathrm{mV} / \mathrm{s}$, owing to the slow lithium-ion diffusion process inside the spinel materials.

First, they applied the conventional approach (i.e., linear or cyclic voltammetry on nonporous electrode is used for the determination of the ESW). As they explained, the limiting redox potentials are ascribed where the de-composition current achieves a predefined level. However, the choice of these cutoff criteria is not supported by any theoretical considerations and is therefore arbitrary. Depending on the authors, cutoff currents of $10 \mu \mathrm{A} / \mathrm{cm}^{2}, 50 \mu \mathrm{A} / \mathrm{cm}^{2}, 0.5$ or $1 \mathrm{~mA} / \mathrm{cm}^{2}$ (most popular) can be chosen. At the end, the difference in stability data imposed by these arbitrary cutoff criteria would be too important to ignore and could lead to conflicting conclusions on the electrolyte stability evaluation.

Moreover, authors claimed that the difference between cutoff currents is not the only reason for the inaccuracy of conventional ESW evaluation methods. To satisfy this conventional method, they identified two prerequisites. First of all, the capacitance of the working electrode must be negligible. Then, the faradic component of the current $\left(\mathrm{I}_{\mathrm{f}}\right)$ must only be dictated by a decomposition mechanism. These settled conditions imply that no other faradic process than electrolyte decomposition takes place and can be sharply approached when nonporous electrodes such as GC or Pt are used in a potentiodynamic experiment due to their stability. This allows the absence of other faradaic processes on the working electrode, except for impurities which can be easily lowered beneath $0.1 \mathrm{~mA} / \mathrm{cm}^{2}$ by rigorous drying of the electrolyte solvent and high purification of the electrolyte solution. However, these ideal conditions are no longer valid for battery applications, where electrode materials are not GC or Pt but rather various composite materials with high capacity which results in additional faradic processes. Furthermore, as active material are often moderate electronic conductors, conductive additives (usually carbon black) are added to the electrode formulation. Thus, the non-faradic part of the current density is no longer negligible as in the ideal case mentioned above. Also, the electrolyte decomposition is affected by the surface of the composite electrode. In conclusion, a narrower ESW should result for real systems and results obtained by conventional analyses with GC or Pt working electrodes cannot describe the anodic stability of electrolytes in real battery devices. Thus, according to the authors, using the same electrode material as that employed with the electrolyte in the real battery cell is the only way to obtain a reliable evaluation of the electrochemical stability window.

About their experimental results, they concluded on the inaccuracy of the stability window measurement when employing nonporous electrodes on the battery electrolyte. They determined that using the electrode material approaching the surface state and surface area of the electrodes used in real devices was the best solution. Authors claim that this solution should be universal, instead of being considered confined to the determination of anodic stability of battery electrolytes only. They also concluded about the fact that few ESW values had been obtained in this way at the time of their article. "That time" was in 1999 and, considering that the first part of this review was only based on recent papers (2019-2020), it seems that twenty years did not make a significant difference.

Other works insist on the use of working electrodes that are as close to the real battery electrodes as possible for ESW investigations. Kasnatscheew et al. performed a study [122] in which they argue that even though a classical measurement (LSV) with an inert working electrode ( $\mathrm{Pt}$, glassy carbon) is well adapted for qualitative comparison, it becomes inappropriate in the prediction of a precise electrochemical stability value. This 
is mainly attributed to the electrode surface area, which is different from that of high surface composite electrodes used in practical devices. This affects the current density and, consequently, the overpotential. Additionally, the electrode composition and surface area are presumed to have an impact on the catalytic activity. To overcome these drawbacks, ESW measurements with LMO electrodes are proposed. This condition reasonably reflects a more realistic battery application. However, concerns and issues linked to this method are still pointed out by authors. There are doubts concerning the validity of this method, as it is not clear whether the obtained stability data can actually be transferred to a real LIB device. First, the chemical composition of the different active materials used in LIBs can, for instance, affect the stability limit via catalytic effects. Then, the determination of the ESW is based on a potentiodynamic principle, while LIB cycling is based on a constant current principle. These differences could have an influence on the determination of the electrolyte stability limit.

\subsection{Other Methods: Improved Setups for the ESW Evaluation}

In addition to the cell construction and the importance of using composite working electrodes, some authors focus on improved ways to use LSV or CV by adjusting parameters (sometimes articles still mention the use of inert working electrodes but with improved LSV or CV set up).

Hallinan et al. [123] proposed an electrochemical approach based on a series of adjusted LSV measurements from different, large over potentials to open circuit voltage, which the authors name "variable reverse linear sweep voltammetry" for evaluating the ESW of solid polymer electrolytes. By applying relaxation times to the cell between each polarization, the first data points of each voltammogram are not limited by mass transfer. This allows the current vs overpotential data to be analyzed by a kinetic model such as the Butler-Volmer one.

Electrochemical measurements were conducted on PEO and SEO (Polystyrene-bpoly(ethyleneoxide)) containing LiTFSI salt in cells with different working electrode materials in both two and three electrode cell configurations at a scanning rate of $15 \mathrm{mV} / \mathrm{s}$. The electrode materials are either used as current collectors in lithium-ion batteries or are intended as inert electrodes for examining oxidative degradation of the polymer electrolytes. An electrochemical impedance spectroscopy (EIS) measurement was performed for every sample before and after every set of electrochemical tests to ensure that the sample was still exhibiting behavior in the same way as a pristine cell. Among the results obtained by these upgraded LSV measurements, the authors found an electrochemical stability for the SEO electrolyte of around $5 \mathrm{~V}$ at $40{ }^{\circ} \mathrm{C}$. Based on their experiments on $\mathrm{Cu} / \mathrm{SEO} / \mathrm{Li}$ cells, they concluded that over-discharge should be avoided to prevent $\mathrm{Cu}$ corrosion (as with liquid electrolytes for battery applications). This work demonstrated a different way of using LSV methods to improve precision in the determination of the ESW.

Kasnatscheew et al. [122] assessed the validity of the potentiodynamic based ESW method by comparing the data with that obtained by galvanostatic method on commercial positive electrodes. They demonstrated the good agreement of the two methods on the determination of the oxidation stabilities of electrolytes. Additionally, they were able to quantify the parasitic reactions by comparing the specific capacity losses obtained in half of the cells during cycling experiments.

Even though this work is devoted to liquid electrolytes, it highlights the use of composite battery electrodes to obtain a more realistic evaluation of the ESW of the electrolyte, and these observations can be transferred to SPEs and SCEs.

A similarly comparative study based on potentiodynamic and galvanostatic results for several active materials was conducted by Homann et al. [124]. In their work, they consider PEO-based SPE under battery cell operation to evidence cell failure and to clear up reported ambiguities regarding oxidation stability. Then, they conducted electrochemical stability evaluations on various cathode materials that are usually used in Lithium batteries (NMC, LMO, LNMO and LFP) via LSV (potentiodynamic) and galvanostatic measurements. The 
onset of oxidation can be detected by an exponential (e.g., Butler-Volmer) current increase and a potential plateau, respectively. LSV measurements were conducted with an applied scanning rate of $0.1 \mathrm{mV} / \mathrm{s}$. For the galvanostatic approach, electrodes were charged with a specific current of $15 \mathrm{~mA} / \mathrm{g}$. Preliminary evaluations were conducted by LSV on a Pt inert working electrode and revealed an Eox around $4.9 \mathrm{~V}$ (the choice of the cut-off current was fixed arbitrary without further explanation). However, as mentioned earlier in this review and by the present authors, the validity of this result is questionable, as the surface area of the $\mathrm{Pt}$ foil is small compared to that of composite battery electrodes in practical cells. Then, they decided to implement a galvanostatic approach to improve the accuracy of their measurement. Thus, LSV on a conductive carbon electrode with higher surface area was applied and a lower onset oxidative potential of $4.6 \mathrm{~V}$ was obtained. Moreover, to be closer to real evaluating characterizations and battery conditions, galvanostatic experiments were performed on a conductive carbon electrode, NMC, LNMO, LMO and LFP working electrodes to confirm the LSV observations. Like the LSV experiment, the galvanostatic approach revealed that the onset of oxidation occurred at $4.6 \mathrm{~V} \mathrm{vs.} \mathrm{Li}^{+} / \mathrm{Li}$, as seen by the respective potential plateau. These results are shown in Figure 7.

(a)

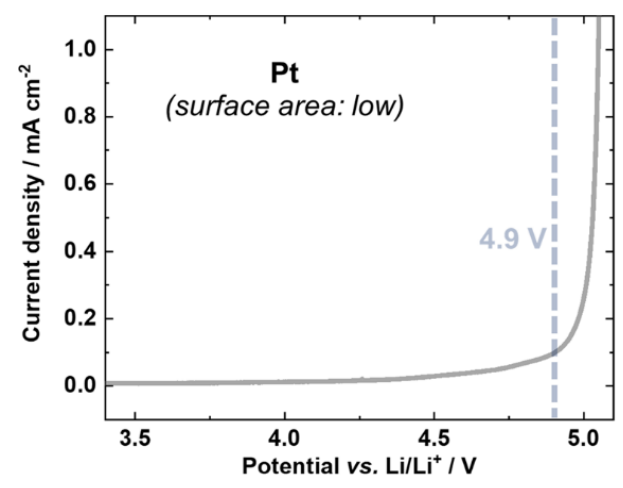

(b)

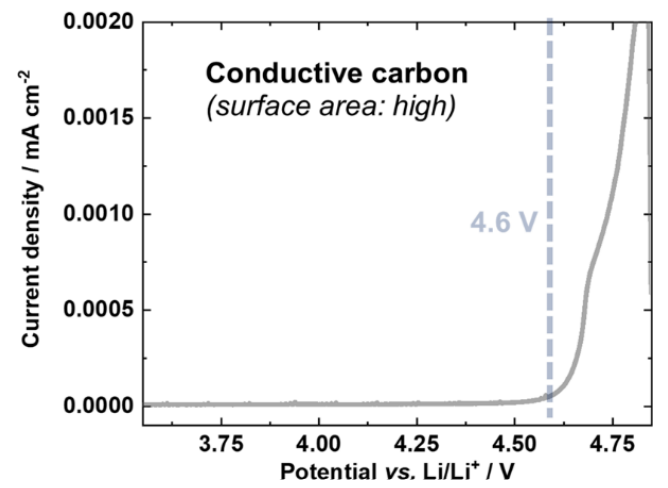

(c)

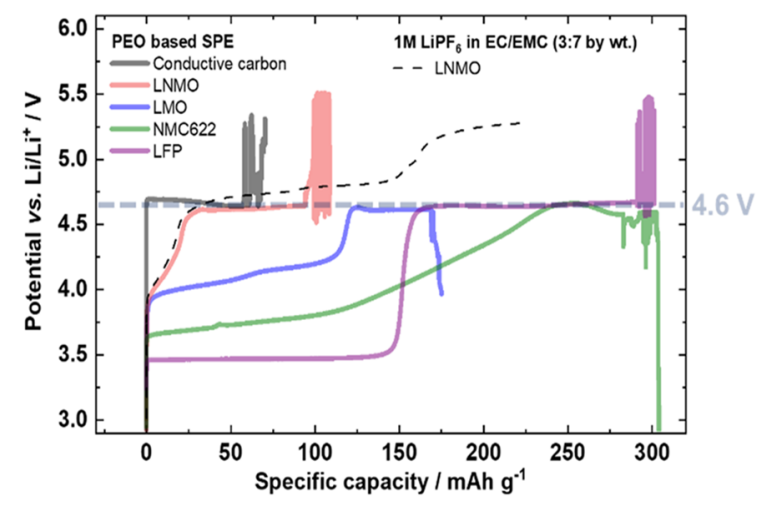

Figure 7. LSVs of PEO based SPE with a scan rate of $0.1 \mathrm{mV} / \mathrm{s}$ on (a) $\mathrm{Pt}$ and (b) conductive carbon working electrode resulting in an exponential increase in current density of 4.9 and $4.6 \mathrm{~V} \mathrm{vs.} \mathrm{Li} / \mathrm{Li}^{+}$, respectively. (c) Determination of the onset of main oxidation of PEO based SPEs via overcharge of the working electrode with a specific current of $15 \mathrm{~mA} \mathrm{~g}^{-1}$ using different positive electrodes. Extract with permission from ref. [124]. Copyright 2020 Springer Nature.

In this study, the authors also concluded that the main source of the sudden battery failure was the $\mathrm{Li} / \mathrm{SPE}$ interface and, particularly, Li dendrite formation and penetration through the SPE membrane rather than the SPE/NMC interface. Finally, they claim that "it is the cell set-up (PEO thickness, negative electrode), which is crucial for the voltage-noise associated failure, and counterintuitively not the high potential of the positive electrode." 
Another interesting work proposes an improved CV setup to analyze the ESW of a solid electrolyte [125]. Dewald et al. applied what they call a "stepwise cyclic voltammetry" method to evaluate the practical oxidative stability of various inorganic solid electrolytes (SE) such as $\mathrm{Li}_{10} \mathrm{GeP}_{2} \mathrm{~S}_{12}, \mathrm{Li}_{2} \mathrm{~S}-\mathrm{P}_{2} \mathrm{~S}_{5}$ or $\mathrm{Li}_{6} \mathrm{PS}_{5} \mathrm{Cl}$. For reasons already mentioned in the previous section about the necessity of avoiding the use of planar electrodes, the authors decided to replace the traditional working electrode by a SE-carbon black composite electrode with higher surface area in order to increase the interfacial contacts between the components and, thus, the sensitivity of the measurement. Additionally, as the electrolytes are expected to decompose in contact with Li metal, indium metal is used as a counter electrode to minimize the reaction current arising from the decomposition on the anode side and to ensure that no additional lithium source is present. Their results, presented in Figure 8, clearly show the impact of the replacement of the inert working electrode by a composite electrode on the ESW determination.

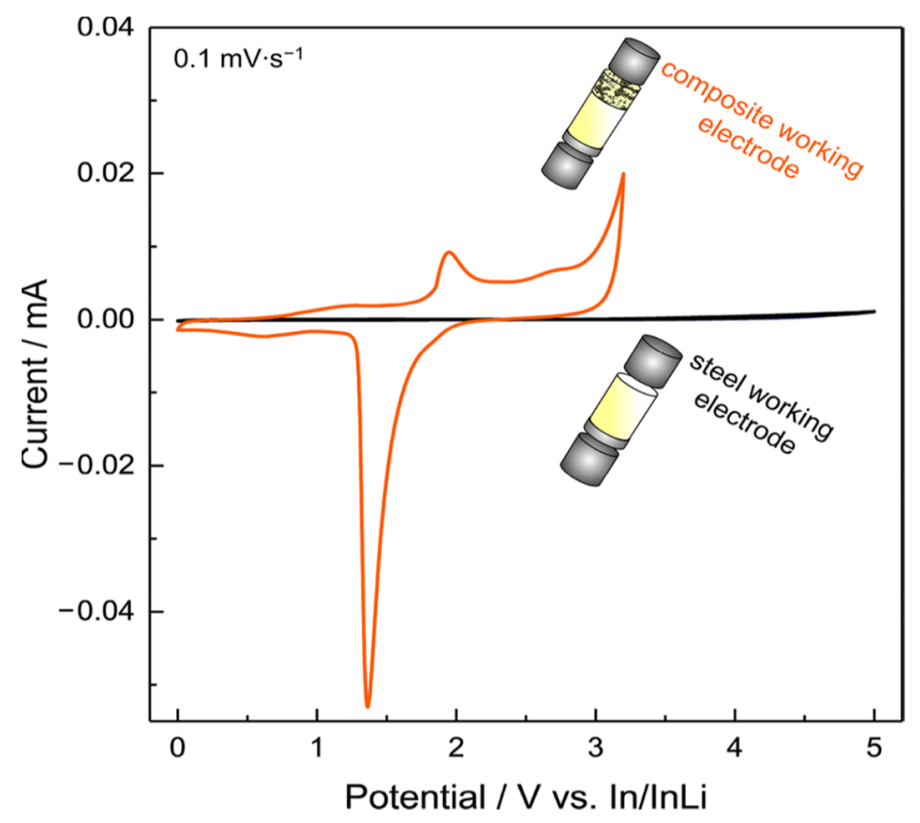

Figure 8. Visual comparison of two types of electrode morphology in CV experiments with the thiophosphate solid electrolyte $\mathrm{Li}_{10} \mathrm{GeP}_{2} \mathrm{~S}_{12}$. Reprinted with permission from ref. [125]. Copyright 2019 American Chemical Society.

By employing In/InLi as both the reference/counter electrode and planar stainless steel as the working electrode, only small currents are detected (black curve). Using a carbon-solid electrolyte composite electrode to the cell (orange curve) leads to higher currents. Consequently, important oxidative decomposition reactions are now visible, mainly due to the huge difference in surface area between a flat (steel) and 3D conductive electrode (composite carbon electrode). In order to determine more precisely the oxidation onset potential of the electrolyte they established a stepwise $C V$ approach. Each CV was measured twice at a low scan rate $(0.1 \mathrm{mV} / \mathrm{s})$ followed by a stepwise increase of the potential range by $0.1 \mathrm{~V}$ up to $4.4 \mathrm{~V}$ vs. $\mathrm{In} / \mathrm{InLi}$ (approx. $5 \mathrm{~V}$ vs. $\mathrm{Li}^{+} / \mathrm{Li}$ ). Authors once again pointed out the necessity of avoiding the use of classical working planar electrodes (SS, Pt) for a better evaluation of the ESW. Their stepwise cyclic voltammetry method could be transferred to the evaluation of SPEs and SCEs. Other works propose the use of solid electrolyte composite electrodes for better ESW evaluations with carbon [126]. It has to be noted that the use of carbon for such measurement could be biased by the presence of residual water within the carbon. Careful drying of carbon is therefore required [125]. Other authors will then prefer gold to carbon for instance [127].

Lastly, Amanchukwu et al. [128] synthesized a new class of fluorinated ether electrolytes that combine the oxidative stability of hydrofluoroethers (HFEs) with the ionic 
conductivity of ethers in a single compound. Among their main results, they showed that their fluorinated ether electrolytes can achieve an ionic conductivity of $2.7 \times 10^{-4} \mathrm{~S} / \mathrm{cm}$ at $30{ }^{\circ} \mathrm{C}$ with a higher oxidative stability of up to $5.6 \mathrm{~V}$ compared to classical ether electrolytes. They used two methods to determine the oxidative stability of the electrolytes. In the first approach they used a classical LSV measurement in a SS/Li cell with an applied scanning rate of $0.1 \mathrm{mV} / \mathrm{s}$ from an open circuit to $6 \mathrm{~V}$. They observed good electrochemical stabilities up to $5 \mathrm{~V}$. They also used potentiostatic holds (Figure 9), also called Potentiostatic Intermittent Titration Technique (PITT), to accurately probe the oxidative stability of the fluorinated ether electrolytes. They argue that long Potentiostatic hold experiments are less sensitive to the influence of impurities which could lead to an early increase of the current in LSV experiments not corresponding to the actual oxidation of the compound. Finally, their conclusions were made by using a stainless steel, aluminum, or Ni-rich NMC 811 electrodes with different electrolytes and by holding the potential for $3 \mathrm{~h}$ at increasingly higher potentials. The recorded current should decrease if no undesired Faradaic reactions occurs. Their best synthesized fluorinated ether electrolyte reached an oxidative stability of $5.6 \mathrm{~V}$. Despite, the fact that this study was conducted on liquid electrolytes, the electrochemical "potentiostatic holds" method could serve as a solid base and could be extended to the ESW evaluation of Solid polymer electrolytes. For instance, Zhang et al. [129] used this method of potentiostatic holds to determine the anodic stability of different polymer electrolytes.

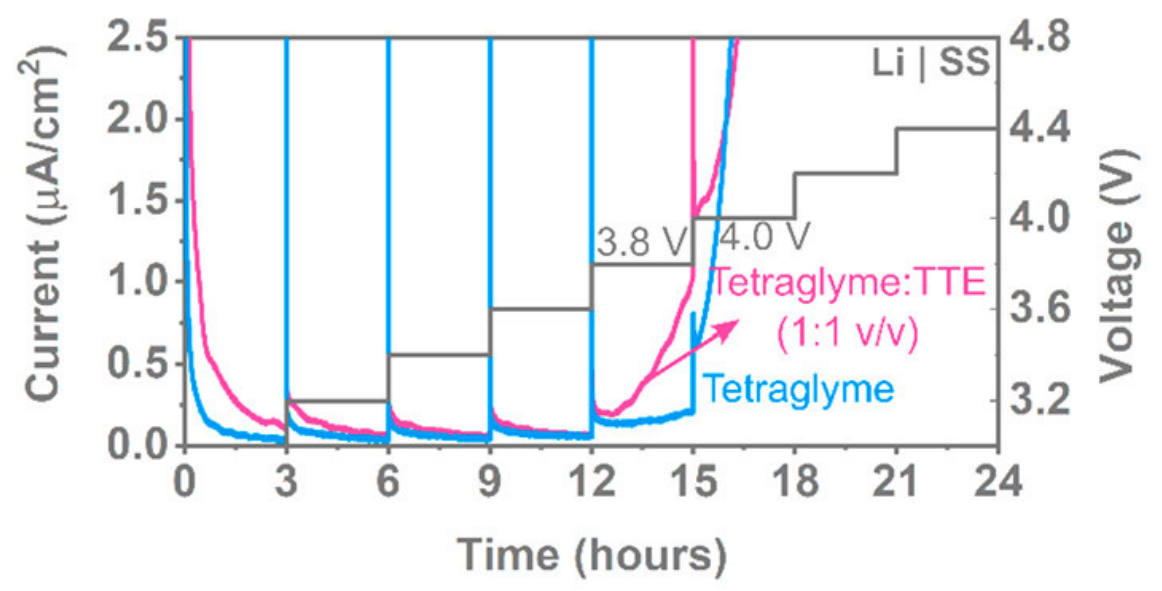

Figure 9. Potentiostatic holds for $3 \mathrm{~h}$ at different voltages with stainless steel as the working electrode and $0.1 \mathrm{M}$ LiFSA in tetraglyme and tetraglyme:TTE. Reprinted with permission from ref. [128]. Copyright 2020 American Chemical Society.

Recently, Li et al. [130] determined the absolute anodic stability threshold of polymer electrolytes via a capacity-based electrochemical method. The objective was to address the limitations imposed by traditional approaches such as LSV. The authors claim that "the inconsistency of LSV is intrinsic to the method". The comparison of electrolytes with distinct conductivities is problematic due to the proportionality of the current density and the electrolyte conductivity. Mass transport limitations cause difficulty in the theoretical analysis and lead to greater error for any method based on current density. Their point is clearly presented in Figure 10.

The authors explain that close to the true stability potential of the electrolyte ( $\left.\mathrm{E}_{\text {onset }}\right)$, the Faradaic current ( $i_{\text {onset }}$ ) and the capacitive current ( $\left.i_{C}\right)$ may be too intricate to be distinguished. Thus, to clearly assign a faradic reaction, a significant increase of the observed current density is needed and the systematic error is the difference between $i_{\text {onset }}$ and $i_{\text {obs }}$. Due to the slow kinetics and low diffusion processes in solid state systems, the i-E curve will be flattened, and a larger error is expected compared to liquid electrolytes. Also, the shape of the voltammogramm can influence the value of the systematic error which becomes unique to each case and quasi-impossible to correct between samples or by 
repeated measurements. Thus, a noticeable disparity is expected to be inherent to the LSV method for the ESW determination of polymer electrolytes.

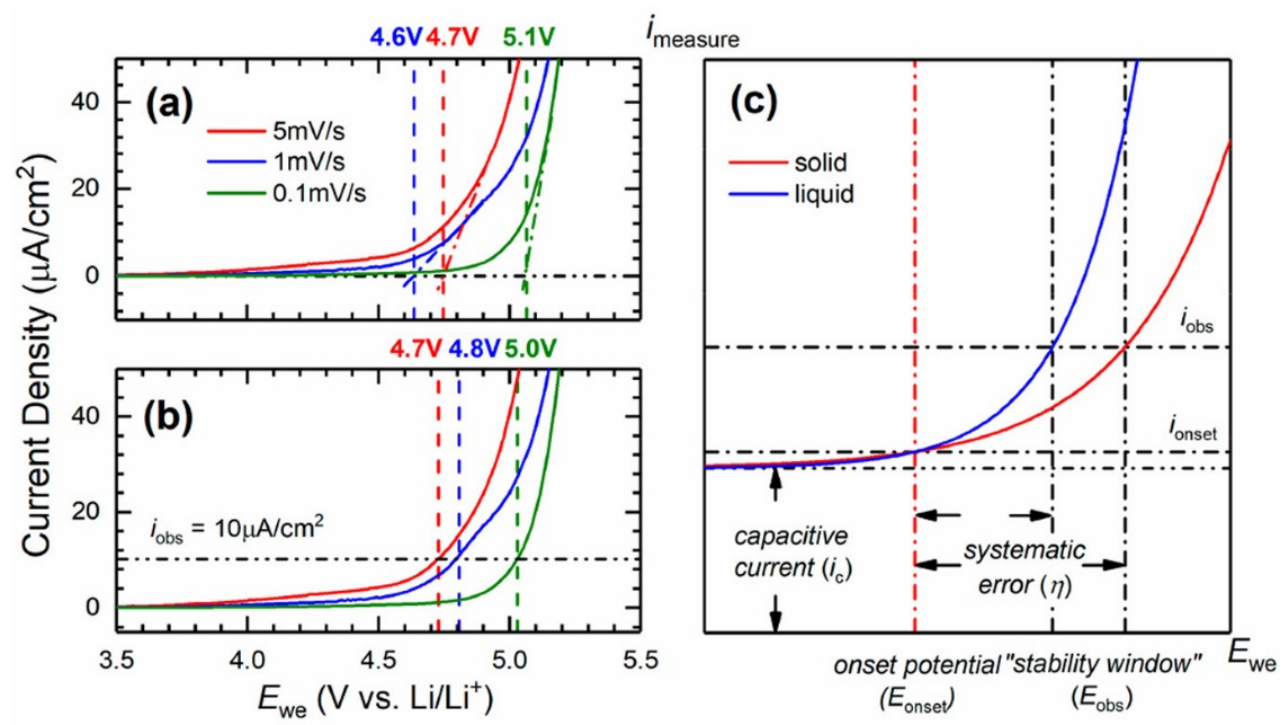

Figure 10. Linear sweep voltammogram of PEO:LiTFSI $(\mathrm{O} / \mathrm{Li}=10)$ from 3.5 to $5.5 \mathrm{~V} \mathrm{vs}$. $\mathrm{Li}^{+} / \mathrm{Li}$ at room temperature. Examples of "stability thresholds" determined by (a) extrapolating the voltammogram and (b) using an arbitrary onset current density. (c) Description of the systematic error in estimating the oxidative stability from current-based methods. Reprinted with permission from ref. [130]. Copyright 2021 American Chemical Society.

Thus, in order to overcome these limitations, they developed an alternative method based on capacity measurements which they named the reversibility test. Briefly, a cyclic voltammetry is performed, and the charge capacities of the cathodic and anodic responses are compared. The ratio between the anodic and the cathodic capacity corresponds to the irreversibility of the process. The capacity ratio remains similar when the electrolyte is electrochemically stable but varies when the potentials exceed the stability threshold of the electrolyte. By this method, the anodic stabilities of poly(ethylene oxide) (PEO) and hydrogenated nitrile butadiene rubber (HNBR), both blended with lithium bis(trifluoromethanesulfonyl) imide (LiTFSI), were identified to be 3.6 and $3.7 \mathrm{~V}$ vs. $\mathrm{Li}^{+} / \mathrm{Li}$, respectively.

Finally, other studies use computational methods (as DFT calculations) to determine the electrochemical stability of liquid and solid electrolytes [131,132] or a complementary study involving both experimental and computational methods [126,127,133-135]. In their work, Thompson et al. [134] proposed a complementary computational/experimental work by using alternating current electrochemical impedance spectroscopy, direct current chronoamperometry, and optical absorption band gap measurements combined with firstprinciples calculations to characterize the electrochemical window of the $\mathrm{Li}_{7} \mathrm{La}_{3} \mathrm{Zr}_{2} \mathrm{O}_{12}$ (LLZO) solid electrolyte. These first-principles calculations were used to predict the density of states (DOS), band gap, and absolute positions of the band edges for LLZO. Authors employed three different levels of theory: (1) the semi-local generalized gradient approximation (DFT-GGA) of Perdew, Burke, and Ernzerhof (PBE); (2) the hybrid functional of Heyd, Scuseria, and Ernzerhof (HSE06); and (3) quasi-particle (QP) calculations based on many-body perturbation theory (G0W0 method). These methods were already used to predict the ESW of liquid electrolytes at electrode interfaces. This work is one of the good examples of the complementarity between experimental and computational methods that can improve the accuracy of the ESW evaluation of electrolytes including SPEs and SCEs. 


\subsection{Final Validation Tests}

Ultimately, the objective of the present manuscript concerns not only the intrinsic stability of the electrolyte but also the electrochemical stability of the entire battery cell. As discussed before, in addition to the use of improved setups, performing tests with real battery electrode materials (cf. Section 3.1) in full cell configuration is critical for the validation of the overall electrochemical stability of the device. In such cases, the stability of the cell is diagnosed via the monitoring of the Coulombic efficiency and capacity retention. A Coulombic efficiency of at least $>99.9 \%$ upon prolonged $99.9 \%$ is targeted to achieve high stability [136]. However, the difficulty of building an optimized and operating battery cell must be kept in mind. Assembling such cell implies the selection of various materials including the current collector, the choice and quality of the active materials and metallic lithium $[137,138]$, and the optimisation of a considerable amount of parameters such as the composite electrode formulation [139], the electrodes and solid electrolyte thickness, the crystallinity (single/poly) of the cathode material, the issues associated with the use of metallic lithium [137] and, lastly, interfacial considerations [140,141] and other external controls (cycling current, pressure) [142].

\section{Summary and Outlook}

Based on the experiments that have been discussed in the previous section, general remarks and conclusions can be made.

First, the traditional use of LSV in a Li/electrolyte/SS cell seems to be acceptable for a qualitative approach but not accurate enough for a precise ESW evaluation. The limiting reduction and oxidation potentials are detected where the de-composition current reaches a predefined value. However, the choice of these cutoff criteria has no theoretical significance and is therefore completely arbitrary. Indeed, it can be tricky to discriminate the capacitive current from the faradic current which will depend of the studied material/electrolyte, the architecture of the working electrode (flat vs. 3D) and its type (carbon vs. $\mathrm{Pt}, \mathrm{Au} \ldots$ ). Thus, depending on the authors, arbitrary cutoff currents of $10 \mu \mathrm{A} / \mathrm{cm}^{2}, 50 \mu \mathrm{A} / \mathrm{cm}^{2}$, 0.5 , or $1 \mathrm{~mA} / \mathrm{cm}^{2}$ are regularly chosen. Moreover, a large range of scanning rates $(0.1$ to $10-50 \mathrm{mV} / \mathrm{s}$ ) is used during testing. The difference in stability data is too significant to ignore and can lead to conflicting conclusions (often an overestimated value) when evaluating ESW data.

Also, several authors agreed that it was necessary to avoid the use of planar inert electrodes (SS, Pt ... ) for the evaluation of the ESW. Indeed, the use of planar electrodes often leads to an overestimated ESW value due to the small surface area and, thus, diminished contact with electrolyte which affects the current density and influences the overpotential. Thus, the association between the classical LSV and cell configurations with planar electrodes generally leads to misestimated ESW values. It is very surprising that a lot of studies still employ this setup for the determination of the ESW.

Finally, to efficiently evaluate the ESW, the two major aspects that must be considered are (i) a suitable cell configuration and (ii) an appropriate method of evaluation.

In regard to point (i), it is clear that the evaluation of the ESW must be conducted on cells containing a composite working electrode to increase the interfacial contacts with the electrolyte, compared to the commonly used planar electrodes, and to better simulate the real electrolyte environment present in a battery cell. This can be a solid electrolyte/carbon composite electrode (assuming no interfacial reaction happens at the surface of CB due to surface groups and/or remaining water) or the electrode material really used in the battery cell (LFP, LMO ... )

Concerning point (ii), upgraded methods such as improved potentiodynamic techniques (CV or LSV using improved setups), PITT-type evaluation with impedance measurements, or galvanostatic techniques must be preferentially used. Performing these experiments with low scanning rates is also an important kinetic factor with respect to the sluggish degradation reactions in the complete solid state. Also, the complementarity of computational methods is beneficial for a better clarification of the ESW. 
Even if all the upgraded methods for ESW evaluation presented in this study are not always specifically developed for the analysis of solid electrolytes, it is evident that those methods can and should be extended to solid-state systems for an accurate determination of the ESW of Solid Polymer Electrolytes and Solid Composites Electrolytes.

Also, we should pay more attention to the formation of the electrolyte degradation products. A better identification and characterization of such products could be the key to define precisely the ESW, to avoid their formation, to eliminate them, or eventually to limit their formation.

Finally, after a precise evaluation of the ESW of the electrolyte itself, the ultimate stability evaluation must be performed in full battery cells while keeping in mind the variety of parameters/components to optimize inside the cell. Currently, this is still a huge challenge to overcome for the future development of all solid-state lithium batteries.

Author Contributions: Conceptualization, A.M., S.R., D.L. and M.D.; writing-original draft preparation, A.M.; writing-review and editing, A.M., S.R., D.L. and M.D.; supervision, M.D.; project administration, S.R., D.L. and M.D.; funding acquisition, M.D. All authors have read and agreed to the published version of the manuscript.

Funding: For this study: the authors acknowledge the financial support provided by a grant from the Natural Sciences and Engineering Research Council of Canada (NSERC RDCPJ 528052-18) and Total Energies Canada.

Institutional Review Board Statement: Not applicable.

Informed Consent Statement: Not applicable.

Acknowledgments: Special thanks to Gabrielle Foran who proofread the article to correct and improve the English.

Conflicts of Interest: The authors declare no conflict of interest.

\section{References}

1. Armand, M.; Axmann, P.; Bresser, D.; Copley, M.; Edström, K.; Ekberg, C.; Guyomard, D.; Lestriez, B.; Novák, P.; Petranikova, M.; et al. Lithium-ion batteries-Current state of the art and anticipated developments. J. Power Sources 2020, 479, 228708. [CrossRef]

2. Duan, J.; Tang, X.; Dai, H.; Yang, Y.; Wu, W.; Wei, X.; Huang, Y. Building Safe Lithium-Ion Batteries for Electric Vehicles: A Review. Electrochem. Energy Rev. 2020, 3, 1-42. [CrossRef]

3. Sun, P.; Bisschop, R.; Niu, H.; Huang, X. A Review of Battery Fires in Electric Vehicles. Fire Technol. 2020, 56, 1361-1410. [CrossRef]

4. Zheng, F.; Kotobuki, M.; Song, S.; Lai, M.O.; Lu, L. Review on solid electrolytes for all-solid-state lithium-ion batteries. J. Power Sources 2018, 389, 198-213. [CrossRef]

5. Yao, P.; Yu, H.; Ding, Z.; Liu, Y.; Lu, J.; Lavorgna, M.; Wu, J.; Liu, X. Review on Polymer-Based Composite Electrolytes for Lithium Batteries. Front. Chem. 2019, 7, 522. [CrossRef] [PubMed]

6. Ye, F.; Liao, K.; Ran, R.; Shao, Z. Recent Advances in Filler Engineering of Polymer Electrolytes for Solid-State Li-Ion Batteries: A Review. Energy Fuels 2020, 34, 9189-9207. [CrossRef]

7. Ohno, S.; Bernges, T.; Buchheim, J.; Duchardt, M.; Hatz, A.-K.; Kraft, M.A.; Kwak, H.; Santhosha, A.L.; Liu, Z.; Minafra, N.; et al. How Certain Are the Reported Ionic Conductivities of Thiophosphate-Based Solid Electrolytes? An Interlaboratory Study. ACS Energy Lett. 2020, 5, 910-915. [CrossRef]

8. Wu, Z.; Xie, Z.; Yoshida, A.; Wang, Z.; Hao, X.; Abudula, A.; Guan, G. Utmost limits of various solid electrolytes in all-solid-state lithium batteries: A critical review. Renew. Sustain. Energy Rev. 2019, 109, 367-385. [CrossRef]

9. Stephan, A.M.; Nahm, K. Review on composite polymer electrolytes for lithium batteries. Polymer 2006, 47, 5952-5964. [CrossRef]

10. Fenton, D.; Parker, J.; Wright, P. Complexes of alkali metal ions with poly (ethylene oxide). Polymer 1973, 14, 589. [CrossRef]

11. Wright, P.V. Electrical conductivity in ionic complexes of poly (ethylene oxide). Br. Polym. J. 1975, 7, 319-327. [CrossRef]

12. Armand, M.; Chabagno, J.; Duclot, M. Poly-ethers as solid electrolytes. In Fast Ion Transport in Solids: Electrodes, and Electrolytes. Proceedings of the International Conference on Fast Ion Transport in Solids, Electrodes, and Electrolytes, Lake Geneva, WI, USA, 21-25 May 1979; Vashishta, P., Mundy, J.N., Shenoy, G.K., Eds.; North Holland: Amsterdam, The Netherlands, 1979; pp. 131-136; ISBN 0444003533.

13. Michael, M.; Jacob, M.; Prabaharan, S.; Radhakrishna, S. Enhanced lithium ion transport in PEO-based solid polymer electrolytes employing a novel class of plasticizers. Solid State Ion. 1997, 98, 167-174. [CrossRef]

14. Gorecki, W.; Jeannin, M.; Belorizky, E.; Roux, C.; Armand, M. Physical properties of solid polymer electrolyte PEO(LiTFSI) complexes. J. Phys. Condens. Matter 1995, 7, 6823-6832. [CrossRef] 
15. Walker, C.W.; Salomon, M. Improvement of Ionic Conductivity in Plasticized PEO-Based Solid Polymer Electrolytes. J. Electrochem. Soc. 1993, 140, 3409-3412. [CrossRef]

16. Deng, P.; Zhang, H.; Feng, W.; Zhou, Z.; Armand, M.; Nie, J. Lithium (fluorosulfonyl)(pentafluoroethylsulfonyl) imide/poly (ethylene oxide) polymer electrolyte: Physical and electrochemical properties. Solid State Ion. 2019, 338, 161-167. [CrossRef]

17. Seo, Y.; Jung, Y.-C.; Park, M.-S.; Kim, D.-W. Solid polymer electrolyte supported by porous polymer membrane for all-solid-state lithium batteries. J. Membr. Sci. 2020, 603, 117995. [CrossRef]

18. Liu, K.; Zhang, Q.; Thapaliya, B.P.; Sun, X.-G.; Ding, F.; Liu, X.; Zhang, J.; Dai, S. In situ polymerized succinonitrile-based solid polymer electrolytes for lithium ion batteries. Solid State Ion. 2020, 345, 115159. [CrossRef]

19. Baroncini, E.A.; Rousseau, D.M.; Strekis, C.A.; Stanzione, J.F. Optimizing conductivity and cationic transport in crosslinked solid polymer electrolytes. Solid State Ion. 2020, 345, 115161. [CrossRef]

20. Yuan, H.; Luan, J.; Yang, Z.; Zhang, J.; Wu, Y.; Lu, Z.; Liu, H. Single Lithium-Ion Conducting Solid Polymer Electrolyte with Superior Electrochemical Stability and Interfacial Compatibility for Solid-State Lithium Metal Batteries. ACS Appl. Mater. Interfaces 2020, 12, 7249-7256. [CrossRef]

21. Liu, L.; Lyu, J.; Mo, J.; Yan, H.; Xu, L.; Peng, P.; Li, J.; Jiang, B.; Chu, L.; Li, M. Comprehensively-upgraded polymer electrolytes by multifunctional aramid nanofibers for stable all-solid-state Li-ion batteries. Nano Energy 2020, 69, 104398. [CrossRef]

22. Liang, J.; Sun, Y.; Zhao, Y.; Sun, Q.; Luo, J.; Zhao, F.; Lin, X.; Li, X.; Li, R.; Zhang, L.; et al. Engineering the conductive carbon/PEO interface to stabilize solid polymer electrolytes for all-solid-state high voltage LiCoO2 batteries. J. Mater. Chem. A 2019, 8 , 2769-2776. [CrossRef]

23. Wu, Z.; Xie, Z.; Yoshida, A.; Wang, J.; Yu, T.; Wang, Z.; Hao, X.; Abudula, A.; Guan, G. Nickel phosphate nanorod-enhanced polyethylene oxide-based composite polymer electrolytes for solid-state lithium batteries. J. Colloid Interface Sci. 2020, 565, 110-118. [CrossRef]

24. Cholant, C.M.; Krüger, L.; Balboni, R.D.C.; Rodrigues, M.P.; Tavares, F.C.; Peres, L.L.; Flores, W.H.; Gündel, A.; Pawlicka, A.; Avellaneda, C.O. Synthesis and characterization of solid polymer electrolyte based on poly(vinyl alcohol)/gum $\mathrm{Arabic} / \mathrm{LiClO} 4$. Ionics 2020, 26, 2941-2948. [CrossRef]

25. Bergfelt, A.; Hernández, G.; Mogensen, R.; Lacey, M.J.; Mindemark, J.; Brandell, D.; Bowden, T.M. Mechanically Robust Yet Highly Conductive Diblock Copolymer Solid Polymer Electrolyte for Ambient Temperature Battery Applications. ACS Appl. Polym. Mater. 2019, 2, 939-948. [CrossRef]

26. Jo, Y.H.; Li, S.; Zuo, C.; Zhang, Y.; Gan, H.; Li, S.; Yu, L.; He, D.; Xie, X.; Xue, Z. Self-Healing Solid Polymer Electrolyte Facilitated by a Dynamic Cross-Linked Polymer Matrix for Lithium-Ion Batteries. Macromolecules 2020, 53, 1024-1032. [CrossRef]

27. Ben Youcef, H.; Orayech, B.; del Amo, J.M.L.; Bonilla, F.; Shanmukaraj, D.; Armand, M. Functionalized cellulose as quasi single-ion conductors in polymer electrolyte for all-solid-state Li/Na and Li S batteries. Solid State Ion. 2020, 345, 115168. [CrossRef]

28. Khani, H.; Kalami, S.; Goodenough, J.B. Micropores-in-macroporous gel polymer electrolytes for alkali metal batteries. Sustain. Energy Fuels 2019, 4, 177-189. [CrossRef]

29. Zhao, Y.; Bai, Y.; Liu, A.; Li, W.; An, M.; Bai, Y.; Chen, G. Polymer electrolyte with dual functional groups designed via theoretical calculation for all-solid-state lithium batteries. J. Power Sources 2020, 450, 227614. [CrossRef]

30. Wu, N.; Chien, P.-H.; Li, Y.; Dolocan, A.; Xu, H.; Xu, B.; Grundish, N.S.; Jin, H.; Hu, Y.-Y.; Goodenough, J.B. Fast Li ${ }^{+}$Conduction Mechanism and Interfacial Chemistry of a NASICON/Polymer Composite Electrolyte. J. Am. Chem. Soc. 2020, 142, $2497-2505$. [CrossRef]

31. Meng, N.; Zhang, H.; Lianli, S.; Lian, F. Salt-with-Salt, a novel strategy to design the flexible solid electrolyte membrane for highly safe lithium metal batteries. J. Membr. Sci. 2020, 597, 117768. [CrossRef]

32. Zhou, B.; Jiang, J.; Zhang, F.; Zhang, H. Crosslinked poly(ethylene oxide)-based membrane electrolyte consisting of polyhedral oligomeric silsesquioxane nanocages for all-solid-state lithium ion batteries. J. Power Sources 2020, 449, 227541. [CrossRef]

33. Tian, X.; Yang, P.; Yi, Y.; Liu, P.; Wang, T.; Shu, C.; Qu, L.; Tang, W.; Zhang, Y.; Li, M.; et al. Self-healing and high stretchable polymer electrolytes based on ionic bonds with high conductivity for lithium batteries. J. Power Sources 2020, 450, 227629. [CrossRef]

34. Cha, J.H.; Didwal, P.N.; Kim, J.M.; Chang, D.R.; Park, C.-J. Poly(ethylene oxide)-based composite solid polymer electrolyte containing $\mathrm{Li}_{7} \mathrm{La}_{3} \mathrm{Zr}_{2} \mathrm{O}_{12}$ and poly(ethylene glycol) dimethyl ether. J. Membr. Sci. 2020, 595, 117538. [CrossRef]

35. Tan, X.; Wu, Y.; Tang, W.; Song, S.; Yao, J.; Wen, Z.; Lu, L.; Savilov, S.V.; Hu, N.; Molenda, J. Preparation of Nanocomposite Polymer Electrolyte via In Situ Synthesis of $\mathrm{SiO}_{2}$ Nanoparticles in PEO. Nanomaterials 2020, 10, 157. [CrossRef]

36. Li, Y.; Sun, Z.; Liu, D.; Gao, Y.; Wang, Y.; Bu, H.-T.; Li, M.; Zhang, Y.; Gao, G.; Ding, S. A composite solid polymer electrolyte incorporating $\mathrm{MnO}_{2}$ nanosheets with reinforced mechanical properties and electrochemical stability for lithium metal batteries. J. Mater. Chem. A 2020, 8, 2021-2032. [CrossRef]

37. Zhang, J.; Wang, S.; Han, D.; Xiao, M.; Sun, L.; Meng, Y. Lithium (4-styrenesulfonyl) (trifluoromethanesulfonyl) imide based single-ion polymer electrolyte with superior battery performance. Energy Storage Mater. 2020, 24, 579-587. [CrossRef]

38. Cao, X.; Cheng, J.; Zhang, X.; Zhou, D.; Tong, Y. Composite Polymer Electrolyte based on Liquid Crystalline Copolymer with High-temperature Stability and Bendability for All-solid-state Lithium-ion Batteries. Int. J. Electrochem. Sci. 2020, 15, 677-695. [CrossRef] 
39. Zhang, Z.; You, J.; Zhang, S.; Wang, C.; Zhou, Y.; Li, J.; Huang, L.; Sun, S. Metal Organic Framework Nanorod Doped Solid Polymer Electrolyte with Decreased Crystallinity for High-Performance All-Solid-State Lithium Batteries. ChemElectroChem. 2019, 7, 1125-1134. [CrossRef]

40. Zhang, Z.; Huang, Y.; Gao, H.; Hang, J.; Li, C.; Liu, P. MOF-derived ionic conductor enhancing polymer electrolytes with superior electrochemical performances for all solid lithium metal batteries. J. Membr. Sci. 2020, 598, 117800. [CrossRef]

41. Dhatarwal, P.; Sengwa, R. Dielectric relaxation, Li-ion transport, electrochemical, and structural behaviour of $\mathrm{PEO} / \mathrm{PVDF} / \mathrm{LiClO} 4 /$ $\mathrm{TiO}_{2}$ /PC-based plasticized nanocomposite solid polymer electrolyte films. Compos. Commun. 2020, 17, 182-191. [CrossRef]

42. Ouhib, F.; Meabe, L.; Mahmoud, A.; Grignard, B.; Thomassin, J.-M.; Boschini, F.; Zhu, H.; Forsyth, M.; Mecerreyes, D.; Detrembleur, C. Influence of the Cyclic versus Linear Carbonate Segments in the Properties and Performance of $\mathrm{CO}_{2}-\mathrm{Sourced}$ Polymer Electrolytes for Lithium Batteries. ACS Appl. Polym. Mater. 2020, 2, 922-931. [CrossRef]

43. Wang, Q.; Cui, Z.; Zhou, Q.; Shangguan, X.; Du, X.; Dong, S.; Qiao, L.; Huang, S.; Liu, X.; Tang, K.; et al. A supramolecular interaction strategy enabling high-performance all solid state electrolyte of lithium metal batteries. Energy Storage Mater. 2020, 25, 756-763. [CrossRef]

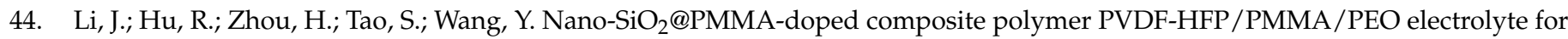
lithium metal batteries. J. Mater. Sci. Mater. Electron. 2020, 31, 2708-2719. [CrossRef]

45. Wang, Q.; Wu, J.-F.; Yu, Z.-Y.; Guo, X. Composite polymer electrolytes reinforced by two-dimensional layer-double-hydroxide nanosheets for dendrite-free lithium batteries. Solid State Ion. 2020, 347, 115275. [CrossRef]

46. Ryu, H.-M.; Kim, M.Y.; Jung, H.Y.; Lim, J.S.; Kim, Y.A.; Kim, H.-S. Fabrication and electrochemical behavior of thin composite solid electrolyte for all-solid lithium batteries. Ionics 2020, 26, 2863-2874. [CrossRef]

47. Zhou, X.; Jiang, H.; Zheng, H.; Sun, Y.; Liang, X.; Xiang, H. Nonflammable hybrid solid electrolyte membrane for a solid-state lithium battery compatible with conventional porous electrodes. J. Membr. Sci. 2020, 603, 117820. [CrossRef]

48. Li, A.; Liao, X.; Zhang, H.; Shi, L.; Wang, P.; Cheng, Q.; Borovilas, J.; Li, Z.; Huang, W.; Fu, Z.; et al. Nacre-Inspired Composite Electrolytes for Load-Bearing Solid-State Lithium-Metal Batteries. Adv. Mater. 2020, 32, e1905517. [CrossRef]

49. Ai, S.; Wang, T.; Li, T.; Wan, Y.; Xu, X.; Lu, H.; Qu, T.; Luo, S.; Jiang, J.; Yu, X.; et al. A Chitosan/Poly(ethylene oxide)-Based Hybrid Polymer Composite Electrolyte Suitable for Solid-State Lithium Metal Batteries. ChemistrySelect 2020, 5, 2878-2885. [CrossRef]

50. Bi, J.; Mu, D.; Wu, B.; Fu, J.; Yang, H.; Mu, G.; Zhang, L.; Wu, F. A hybrid solid electrolyte $\mathrm{Li}_{0.33} \mathrm{La}_{0.557} \mathrm{TiO}_{3} / \mathrm{poly}_{(\mathrm{acylonitrile})}$ membrane infiltrated with a succinonitrile-based electrolyte for solid state lithium-ion batteries. J. Mater. Chem. A 2020, 8, 706-713. [CrossRef]

51. Pareek, T.; Dwivedi, S.; Ahmad, S.A.; Badole, M.; Kumar, S. Effect of NASICON-type $\operatorname{LiSnZr}\left(\mathrm{PO}_{4}\right)_{3}$ ceramic filler on the ionic conductivity and electrochemical behavior of PVDF based composite electrolyte. J. Alloys Compd. 2020, 824, 153991. [CrossRef]

52. Xuan, C.; Gao, S.; Wang, Y.; You, Q.; Liu, X.; Liu, J.; Xu, R.; Yang, K.; Cheng, S.; Liu, Z.; et al. In-situ generation of high performance thiol-conjugated solid polymer electrolytes via reliable thiol-acrylate click chemistry. J. Power Sources 2020, 456, 228024. [CrossRef]

53. Sengwa, R.; Dhatarwal, P. Predominantly chain segmental relaxation dependent ionic conductivity of multiphase semicrystalline $\mathrm{PVDF} / \mathrm{PEO} / \mathrm{LiClO}_{4}$ solid polymer electrolytes. Electrochim. Acta 2020, 338, 135890. [CrossRef]

54. Meabe, L.; Goujon, N.; Li, C.; Armand, M.; Forsyth, M.; Mecerreyes, D. Single-Ion Conducting Poly(Ethylene Oxide Carbonate) as Solid Polymer Electrolyte for Lithium Batteries. Batter. Supercaps. 2020, 3, 68-75. [CrossRef]

55. Feng, J.; Ao, X.; Lei, Z.; Wang, J.; Deng, Y.; Wang, C. Hollow nanotubular clay composited comb-like methoxy poly(ethylene glycol) acrylate polymer as solid polymer electrolyte for lithium metal batteries. Electrochim. Acta 2020, 340, 135995. [CrossRef]

56. Grewal, M.S.; Tanaka, M.; Kawakami, H. Fabrication and characterizations of soft and flexible Poly(dimethylsiloxane)incorporated network polymer electrolyte membranes. Polymer 2020, 186, 122045. [CrossRef]

57. Choudhury, S. (Ed.) A Highly Reversible Room-Temperature Lithium Metal Battery Based on Cross-Linked Hairy Nanoparticles. In Rational Design of Nanostructured Polymer Electrolytes and Solid-Liquid Interphases for Lithium Batteries; Springer International Publishing: Cham, Switzerland, 2019; pp. 35-57.

58. Liu, L.; Chu, L.; Jiang, B.; Li, M. Li $\mathrm{Li}_{1.4} \mathrm{Al}_{0.4} \mathrm{Ti}_{1.6}\left(\mathrm{PO}_{4}\right)_{3}$ nanoparticle-reinforced solid polymer electrolytes for all-solid-state lithium batteries. Solid State Ion. 2019, 331, 89-95. [CrossRef]

59. Sasikumar, M.; Jagadeesan, A.; Raja, M.; Krishna, R.H.; Sivakumar, P. The effects of PVAc on surface morphological and electrochemical performance of $\mathrm{P}(\mathrm{VdF}-\mathrm{HFP})$-based blend solid polymer electrolytes for lithium ion-battery applications. Ionics 2018, 25, 2171-2181. [CrossRef]

60. Grewal, M.S.; Tanaka, M.; Kawakami, H. Free-standing polydimethylsiloxane-based cross-linked network solid polymer electrolytes for future lithium ion battery applications. Electrochim. Acta 2019, 307, 148-156. [CrossRef]

61. Huang, Z.; Pan, Q.; Smith, D.M.; Li, C.Y. Plasticized Hybrid Network Solid Polymer Electrolytes for Lithium-Metal Batteries. Adv. Mater. Interfaces 2019, 6, 1801445. [CrossRef]

62. Piana, G.; Bella, F.; Geobaldo, F.; Meligrana, G.; Gerbaldi, C. PEO/LAGP hybrid solid polymer electrolytes for ambient temperature lithium batteries by solvent-free, "one pot" preparation. J. Energy Storage 2019, 26, 100947. [CrossRef]

63. He, K.-Q.; Zha, J.-W.; Du, P.; Cheng, S.H.-S.; Liu, C.; Dang, Z.-M.; Li, R.K.Y. Tailored high cycling performance in a solid polymer electrolyte with perovskite-type $\mathrm{Li}_{0.33} \mathrm{La}_{0.557} \mathrm{TiO}_{3}$ nanofibers for all-solid-state lithium ion batteries. Dalton Trans. 2019, 48, 3263-3269. [CrossRef] 
64. Meabe, L.; Huynh, T.V.; Mantione, D.; Porcarelli, L.; Li, C.; O’Dell, L.; Sardon, H.; Armand, M.; Forsyth, M.; Mecerreyes, D. UV-cross-linked poly(ethylene oxide carbonate) as free standing solid polymer electrolyte for lithium batteries. Electrochim. Acta 2019, 302, 414-421. [CrossRef]

65. Cao, C.; Li, Y.; Feng, Y.; Peng, C.; Li, Z.; Feng, W. A solid-state single-ion polymer electrolyte with ultrahigh ionic conductivity for dendrite-free lithium metal batteries. Energy Storage Mater. 2019, 19, 401-407. [CrossRef]

66. Deka, J.R.; Saikia, D.; Lou, G.-W.; Lin, C.-H.; Fang, J.; Yang, Y.-C.; Kao, H.-M. Design, synthesis and characterization of polysiloxane and polyetherdiamine based comb-shaped hybrid solid polymer electrolytes for applications in electrochemical devices. Mater. Res. Bull. 2019, 109, 72-81. [CrossRef]

67. Imholt, L.; Dörr, T.S.; Zhang, P.; Ibing, L.; Cekic-Laskovic, I.; Winter, M.; Brunklaus, G. Grafted polyrotaxanes as highly conductive electrolytes for lithium metal batteries. J. Power Sources 2019, 409, 148-158. [CrossRef]

68. Ma, Q.; Chakrabarti, A.; Mei, X.; Yue, Z.; Dunya, H.; Filler, R.; Mandal, B.K. New oligoether plasticizers for poly(ethylene oxide)-based solid polymer electrolytes. Ionics 2018, 25, 1633-1643. [CrossRef]

69. Na Choi, B.; Yang, J.H.; Kim, Y.S.; Chung, C.-H. Effect of morphological change of copper-oxide fillers on the performance of solid polymer electrolytes for lithium-metal polymer batteries. RSC Adv. 2019, 9, 21760-21770. [CrossRef]

70. Choudhury, S.; Tu, Z.; Nijamudheen, A.; Zachman, M.J.; Stalin, S.; Deng, Y.; Zhao, Q.; Vu, D.; Kourkoutis, L.F.; Mendoza-Cortes, J.L.; et al. Stabilizing polymer electrolytes in high-voltage lithium batteries. Nat. Commun. 2019, 10, 1-11. [CrossRef]

71. Zhang, Y.; Wang, X.; Feng, W.; Zhen, Y.; Zhao, P.; Cai, Z.; Li, L. Effects of the shapes of BaTiO 3 nanofillers on PEO-based electrolytes for all-solid-state lithium-ion batteries. Ionics 2019, 25, 1471-1480. [CrossRef]

72. Nair, J.R.; Shaji, I.; Ehteshami, N.; Thum, A.; Diddens, D.; Heuer, A.; Winter, M. Solid Polymer Electrolytes for Lithium Metal Battery via Thermally Induced Cationic Ring-Opening Polymerization (CROP) with an Insight into the Reaction Mechanism. Chem. Mater. 2019, 31, 3118-3133. [CrossRef]

73. Li, C.; Huang, Y.; Feng, X.; Zhang, Z.; Liu, P. High electrochemical performance poly(ethylene oxide)/2,4-toluene diisocyante/polyethylene glycol as electrolytes for all-solid-state lithium batteries. J. Membr. Sci. 2019, 587, 117179. [CrossRef]

74. Ma, F.; Zhang, Z.-Q.; Yan, W.; Ma, X.; Sun, D.; Jin, Y.; Chen, X.; He, K. Solid Polymer Electrolyte Based on Polymerized Ionic Liquid for High Performance All-Solid-State Lithium-Ion Batteries. ACS Sustain. Chem. Eng. 2019, 7, 4675-4683. [CrossRef]

75. Niu, C.; Liu, J.; Chen, G.; Liu, C.; Qian, T.; Zhang, J.; Cao, B.; Shang, W.; Chen, Y.; Han, J.; et al. Anion-regulated solid polymer electrolyte enhances the stable deposition of lithium ion for lithium metal batteries. J. Power Sources 2019, 417, 70-75. [CrossRef]

76. Yang, X.; Sun, Q.; Zhao, C.; Gao, X.; Adair, K.R.; Liu, Y.; Luo, J.; Lin, X.; Liang, J.; Huang, H.; et al. High-areal-capacity all-solid-state lithium batteries enabled by rational design of fast ion transport channels in vertically-aligned composite polymer electrodes. Nano Energy 2019, 61, 567-575. [CrossRef]

77. Lu, Y.; He, K.-W.; Zhang, S.-J.; Zhou, Y.-X.; Wang, Z.-B. UV-curable-based plastic crystal polymer electrolyte for high-performance all-solid-state Li-ion batteries. Ionics 2019, 25, 1607-1615. [CrossRef]

78. Huang, S.; Cui, Z.; Qiao, L.; Xu, G.; Zhang, J.; Tang, K.; Liu, X.; Wang, Q.; Zhou, X.; Zhang, B.; et al. An in-situ polymerized solid polymer electrolyte enables excellent interfacial compatibility in lithium batteries. Electrochim. Acta 2019, 299, 820-827. [CrossRef]

79. Wang, Q.; Zhang, Z.; Shen, F.; Zhao, B.; Han, X. Holey graphene oxide as filler to improve electrochemical performance of solid polymer electrolytes. Mater. Express 2019, 9, 1055-1061. [CrossRef]

80. Zhang, N.; He, J.; Han, W.; Wang, Y. Composite solid electrolyte PEO/SN/LiAlO 2 for a solid-state lithium battery. J. Mater. Sci. 2019, 54, 9603-9612. [CrossRef]

81. Zhao, Y.; Wang, Y. Tailored Solid Polymer Electrolytes by Montmorillonite with High Ionic Conductivity for Lithium-Ion Batteries. Nanoscale Res. Lett. 2019, 14, 1-6. [CrossRef] [PubMed]

82. Zhang, Y.; Lu, W.; Cong, L.; Liu, J.; Sun, L.; Mauger, A.; Julien, C.M.; Xie, H.; Liu, J. Cross-linking network based on Poly(ethylene oxide): Solid polymer electrolyte for room temperature lithium battery. J. Power Sources 2019, 420, 63-72. [CrossRef]

83. Zhang, Y.; Wang, X.; Feng, W.; Zhen, Y.; Zhao, P.; Li, L.; Cai, Z. The effects of the size and content of BaTiO 3 nanoparticles on solid polymer electrolytes for all-solid-state lithium-ion batteries. J. Solid State Electrochem. 2019, 23, 749-758. [CrossRef]

84. Rangasamy, V.S.; Thayumanasundaram, S.; Locquet, J.-P. Solid polymer electrolytes with poly(vinyl alcohol) and piperidinium based ionic liquid for Li-ion batteries. Solid State Ion. 2019, 333, 76-82. [CrossRef]

85. Wu, N.; Shi, Y.; Lang, S.; Zhou, J.; Liang, J.; Wang, W.; Tan, S.; Yin, Y.; Wen, R.; Guo, Y. Self-Healable Solid Polymeric Electrolytes for Stable and Flexible Lithium Metal Batteries. Angew. Chem. Int. Ed. 2019, 58, 18146-18149. [CrossRef] [PubMed]

86. Watanabe, T.; Inafune, Y.; Tanaka, M.; Mochizuki, Y.; Matsumoto, F.; Kawakami, H. Development of all-solid-state battery based on lithium ion conductive polymer nanofiber framework. J. Power Sources 2019, 423, 255-262. [CrossRef]

87. Sun, J.; Li, Y.; Zhang, Q.; Hou, C.; Shi, Q.; Wang, H. A highly ionic conductive poly(methyl methacrylate) composite electrolyte with garnet-typed $\mathrm{Li}_{6.75} \mathrm{La}_{3} \mathrm{Zr}_{1.75} \mathrm{Nb}_{0.25} \mathrm{O}_{12}$ nanowires. Chem. Eng. J. 2019, 375, 121922. [CrossRef]

88. Zhu, Q.; Wang, X.; Miller, J.D. Advanced Nanoclay-Based Nanocomposite Solid Polymer Electrolyte for Lithium Iron Phosphate Batteries. ACS Appl. Mater. Interfaces 2019, 11, 8954-8960. [CrossRef]

89. Liu, Q.; Liu, Y.; Jiao, X.; Song, Z.; Sadd, M.; Xu, X.; Matic, A.; Xiong, S.; Song, J. Enhanced ionic conductivity and interface stability of hybrid solid-state polymer electrolyte for rechargeable lithium metal batteries. Energy Storage Mater. 2019, 23, 105-111. [CrossRef] 
90. Li, X.; Zheng, Y.; Pan, Q.; Li, C.Y. Polymerized Ionic Liquid-Containing Interpenetrating Network Solid Polymer Electrolytes for All-Solid-State Lithium Metal Batteries. ACS Appl. Mater. Interfaces 2019, 11, 34904-34912. [CrossRef]

91. Wang, X.; Zhai, H.; Qie, B.; Cheng, Q.; Li, A.; Borovilas, J.; Xu, B.; Shi, C.; Jin, T.; Liao, X.; et al. Rechargeable solid-state lithium metal batteries with vertically aligned ceramic nanoparticle/polymer composite electrolyte. Nano Energy 2019, 60, $205-212$. [CrossRef]

92. Li, Y.; Zhang, W.; Dou, Q.; Wong, K.W.; Ng, K.M. $\mathrm{Li}_{7} \mathrm{La}_{3} \mathrm{Zr}_{2} \mathrm{O}_{12}$ ceramic nanofiber-incorporated composite polymer electrolytes for lithium metal batteries. J. Mater. Chem. A 2019, 7, 3391-3398. [CrossRef]

93. Li, Y.; Sun, Z.; Shi, L.; Lu, S.; Sun, Z.; Shi, Y.; Wu, H.; Zhang, Y.; Ding, S. Poly(ionic liquid)-polyethylene oxide semi-interpenetrating polymer network solid electrolyte for safe lithium metal batteries. Chem. Eng. J. 2019, 375, 121925. [CrossRef]

94. Sun, Y.; Zhan, X.; Hu, J.; Wang, Y.; Gao, S.; Shen, Y.; Cheng, Y.-T. Improving Ionic Conductivity with Bimodal-Sized $\mathrm{Li}_{7} \mathrm{La}_{3} \mathrm{Zr}_{2} \mathrm{O}_{12}$ Fillers for Composite Polymer Electrolytes. ACS Appl. Mater. Interfaces 2019, 11, 12467-12475. [CrossRef]

95. Jo, Y.H.; Zhou, B.; Jiang, K.; Li, S.; Zuo, C.; Gan, H.; He, D.; Zhou, X.; Xue, Z. Self-healing and shape-memory solid polymer electrolytes with high mechanical strength facilitated by a poly(vinyl alcohol) matrix. Polym. Chem. 2019, 10, 6561-6569. [CrossRef]

96. Zhang, B.; Zhang, Y.; Zhang, N.; Liu, J.; Cong, L.; Liu, J.; Sun, L.; Mauger, A.; Julien, C.M.; Xie, H.; et al. Synthesis and interface stability of polystyrene-poly(ethylene glycol)-polystyrene triblock copolymer as solid-state electrolyte for lithium-metal batteries. J. Power Sources 2019, 428, 93-104. [CrossRef]

97. Xiao, Z.; Zhou, B.; Wang, J.; Zuo, C.; He, D.; Xie, X.; Xue, Z. PEO-based electrolytes blended with star polymers with precisely imprinted polymeric pseudo-crown ether cavities for alkali metal ion batteries. J. Membr. Sci. 2019, 576, 182-189. [CrossRef]

98. Raut, P.; Li, S.; Chen, Y.-M.; Zhu, Y.; Jana, S.C. Strong and Flexible Composite Solid Polymer Electrolyte Membranes for Li-Ion Batteries. ACS Omega 2019, 4, 18203-18209. [CrossRef]

99. Yao, W.; Zhang, Q.; Qi, F.; Zhang, J.; Liu, K.; Li, J.; Chen, W.; Du, Y.; Jin, Y.; Liang, Y.; et al. Epoxy containing solid polymer electrolyte for lithium ion battery. Electrochim. Acta 2019, 318, 302-313. [CrossRef]

100. Wang, Z.; Gu, H.; Wei, Z.; Wang, J.; Yao, X.; Chen, S. Preparation of new composite polymer electrolyte for long cycling all-solid-state lithium battery. Ionics 2019, 25, 907-916. [CrossRef]

101. Yu, X.; Wang, L.; Ma, J.; Sun, X.; Zhou, X.; Cui, G. Selectively Wetted Rigid-Flexible Coupling Polymer Electrolyte Enabling Superior Stability and Compatibility of High-Voltage Lithium Metal Batteries. Adv. Energy Mater. 2020, 10. [CrossRef]

102. Wang, W.; Fang, Z.; Zhao, M.; Peng, Y.; Zhang, J.; Guan, S. Solid polymer electrolytes based on the composite of PEO-LiFSI and organic ionic plastic crystal. Chem. Phys. Lett. 2020, 747, 137335. [CrossRef]

103. Gao, J.; Shao, Q.; Chen, J. Lithiated Nafion-garnet ceramic composite electrolyte membrane for solid-state lithium metal battery. J. Energy Chem. 2020, 46, 237-247. [CrossRef]

104. Tang, S.; Lan, Q.; Xu, L.; Liang, J.; Lou, P.; Liu, C.; Mai, L.; Cao, Y.-C.; Cheng, S. A novel cross-linked nanocomposite solid-state electrolyte with super flexibility and performance for lithium metal battery. Nano Energy 2020, 71, 104600. [CrossRef]

105. Xie, Z.; Wu, Z.; An, X.; Yue, X.; Xiaokaiti, P.; Yoshida, A.; Abudula, A.; Guan, G. A sandwich-type composite polymer electrolyte for all-solid-state lithium metal batteries with high areal capacity and cycling stability. J. Membr. Sci. 2020, 596, 117739. [CrossRef]

106. Peng, X.; Huang, K.; Song, S.; Wu, F.; Xiang, Y.; Zhang, X. Garnet-Polymer Composite Electrolytes with High Li ${ }^{+}$Conductivity and Transference Number via Well-Fused Grain Boundaries in Microporous Frameworks. ChemElectroChem 2020, 7, $2389-2394$. [CrossRef]

107. Shi, Y.; Chen, Y.; Liang, Y.; Andrews, J.; Dong, H.; Yuan, M.; Ding, W.; Banerjee, S.; Ardebili, H.; Robertson, M.L.; et al. Chemically inert covalently networked triazole-based solid polymer electrolytes for stable all-solid-state lithium batteries. J. Mater. Chem. A 2019, 7, 19691-19695. [CrossRef]

108. Sun, Z.; Li, Y.; Zhang, S.; Shi, L.; Wu, H.; Bu, H.; Ding, S. g- $\mathrm{C}_{3} \mathrm{~N}_{4}$ nanosheets enhanced solid polymer electrolytes with excellent electrochemical performance, mechanical properties, and thermal stability. J. Mater. Chem. A 2019, 7, 11069-11076. [CrossRef]

109. Yang, K.; Liao, Z.; Zhang, Z.; Yang, L.; Hirano, S.-I. Ionic plastic crystal-polymeric ionic liquid solid-state electrolytes with high ionic conductivity for lithium ion batteries. Mater. Lett. 2019, 236, 554-557. [CrossRef]

110. Chen, Y.; Shi, Y.; Liang, Y.; Dong, H.; Hao, F.; Wang, A.; Zhu, Y.; Cui, X.; Yao, Y. Hyperbranched PEO-Based Hyperstar Solid Polymer Electrolytes with Simultaneous Improvement of Ion Transport and Mechanical Strength. ACS Appl. Energy Mater. 2019, 2, 1608-1615. [CrossRef]

111. Wang, Q.; Liu, X.; Cui, Z.; Shangguan, X.; Zhang, H.; Zhang, J.; Tang, K.; Li, L.; Zhou, X.; Cui, G. A fluorinated polycarbonate based all solid state polymer electrolyte for lithium metal batteries. Electrochim. Acta 2020, 337, 135843. [CrossRef]

112. Xu, Z.; Yang, T.; Chu, X.; Su, H.; Wang, Z.; Chen, N.; Gu, B.; Zhang, H.; Deng, W.; Zhang, H.; et al. Strong Lewis Acid-Base and Weak Hydrogen Bond Synergistically Enhancing Ionic Conductivity of Poly(ethylene oxide)@SiO ${ }_{2}$ Electrolytes for a High Rate Capability Li-Metal Battery. ACS Appl. Mater. Interfaces 2020, 12, 10341-10349. [CrossRef] [PubMed]

113. Huang, Z.; Tong, R.-A.; Zhang, J.; Chen, L.; Wang, C.-A. Blending Poly(ethylene oxide) and $\mathrm{Li}_{6.4} \mathrm{La}_{3} \mathrm{Zr}_{1.4} \mathrm{Ta}_{0.6} \mathrm{O}_{12}$ by $\mathrm{Haake}$ Rheomixer without any solvent: A low-cost manufacture method for mass production of composite polymer electrolyte. J. Power Sources 2020, 451, 227797. [CrossRef]

114. Mousavi, M.P.S.; Dittmer, A.J.; Wilson, B.E.; Hu, J.; Stein, A.; Buhlmann, P. Unbiased Quantification of the Electrochemical Stability Limits of Electrolytes and Ionic Liquids. J. Electrochem. Soc. 2015, 162, A2250-A2258. [CrossRef]

115. Subramania, A.; Sundaram, N.T.K.; Kumar, G.V.; Vasudevan, T. New polymer electrolyte based on (PVA-PAN) blend for Li-ion battery applications. Ionics 2006, 12, 175-178. [CrossRef] 
116. Raghavan, P.; Zhao, X.; Shin, C.; Baek, D.-H.; Choi, J.-W.; Manuel, J.; Heo, M.-Y.; Ahn, J.-H.; Nah, C. Preparation and electrochemical characterization of polymer electrolytes based on electrospun poly(vinylidene fluoride-co-hexafluoropropylene)/polyacrylonitrile blend/composite membranes for lithium batteries. J. Power Sources 2010, 195, 6088-6094. [CrossRef]

117. Du, Y.-L.; Wen, T.-C. The feasibility study of composite electrolytes comprising thermoplastic polyurethane and poly(ethylene oxide). Mater. Chem. Phys. 2001, 71, 62-69. [CrossRef]

118. Shin, J.-H.; Passerini, S. Effect of fillers on the electrochemical and interfacial properties of $\mathrm{PEO}-\mathrm{LiN}\left(\mathrm{SO}_{2} \mathrm{CF}_{2} \mathrm{CF}_{3}\right)_{2} \mathrm{polymer}$ electrolytes. Electrochim. Acta 2004, 49, 1605-1612. [CrossRef]

119. Dong, X.; Yao, J.; Zhu, W.; Huang, X.; Kuai, X.; Tang, J.; Li, X.; Dai, S.; Shen, L.; Yang, R.; et al. Enhanced high-voltage cycling stability of Ni-rich cathode materials via the self-assembly of Mn-rich shells. J. Mater. Chem. A 2019, 7, 20262-20273. [CrossRef]

120. Qiu, Q.-Q.; Shadike, Z.; Wang, Q.-C.; Yue, X.-Y.; Li, X.; Yuan, S.-S.; Fang, F.; Wu, X.-J.; Hunt, A.; Waluyo, I.; et al. Improving the Electrochemical Performance and Structural Stability of the $\mathrm{LiNi}_{0.8} \mathrm{Co}_{0.15} \mathrm{Al}_{0.05} \mathrm{O}_{2}$ Cathode Material at High-Voltage Charging through Ti Substitution. ACS Appl. Mater. Interfaces 2019, 11, 23213-23221. [CrossRef]

121. Xu, K.; Ding, S.P.; Jow, T.R. Toward Reliable Values of Electrochemical Stability Limits for Electrolytes. J. Electrochem. Soc. 1999, 146, 4172-4178. [CrossRef]

122. Kasnatscheew, J.; Streipert, B.; Röser, S.; Wagner, R.; Laskovic, I.C.; Winter, M. Determining oxidative stability of battery electrolytes: Validity of common electrochemical stability window (ESW) data and alternative strategies. Phys. Chem. Chem. Phys. 2017, 19, 16078-16086. [CrossRef]

123. Hallinan, D.T.; Rausch, A.; McGill, B. An electrochemical approach to measuring oxidative stability of solid polymer electrolytes for lithium batteries. Chem. Eng. Sci. 2016, 154, 34-41. [CrossRef]

124. Homann, G.; Stolz, L.; Nair, J.; Laskovic, I.C.; Winter, M.; Kasnatscheew, J. Poly(Ethylene Oxide)-based Electrolyte for Solid-StateLithium-Batteries with High Voltage Positive Electrodes: Evaluating the Role of Electrolyte Oxidation in Rapid Cell Failure. Sci. Rep. 2020, 10, 1-9. [CrossRef] [PubMed]

125. Dewald, G.F.; Ohno, S.; Kraft, M.A.; Koerver, R.; Till, P.; Vargas-Barbosa, N.M.; Janek, J.; Zeier, W.G. Experimental Assessment of the Practical Oxidative Stability of Lithium Thiophosphate Solid Electrolytes. Chem. Mater. 2019, 31, 8328-8337. [CrossRef]

126. Han, F.; Zhu, Y.; He, X.; Mo, Y.; Wang, C. Electrochemical Stability of $\mathrm{Li}_{10} \mathrm{GeP}_{2} \mathrm{~S}_{12}$ and $\mathrm{Li}_{7} \mathrm{La}_{3} \mathrm{Zr}_{2} \mathrm{O}_{12}$ Solid Electrolytes. Adv. Energy Mater. 2016, 6, 1501590. [CrossRef]

127. Benabed, Y.; Rioux, M.; Rousselot, S.; Hautier, G.; Dollé, M. Assessing the Electrochemical Stability Window of NASICON-Type Solid Electrolytes. Front. Energy Res. 2021, 9. [CrossRef]

128. Amanchukwu, C.V.; Yu, Z.; Kong, X.; Qin, J.; Cui, Y.; Bao, Z. A New Class of Ionically Conducting Fluorinated Ether Electrolytes with High Electrochemical Stability. J. Am. Chem. Soc. 2020, 142, 7393-7403. [CrossRef] [PubMed]

129. Zhang, W.; Feng, S.; Huang, M.; Qiao, B.; Shigenobu, K.; Giordano, L.; Lopez, J.; Tatara, R.; Ueno, K.; Dokko, K.; et al. Molecularly Tunable Polyanions for Single-Ion Conductors and Poly(solvate ionic liquids). Chem. Mater. 2021, 33, 524-534. [CrossRef]

130. Li, Z.; Zhao, Y.; Tenhaeff, W.E. Determining the Absolute Anodic Stability Threshold of Polymer Electrolytes: A Capacity-Based Electrochemical Method. Chem. Mater. 2021, 33, 1927-1934. [CrossRef]

131. Binninger, T.; Marcolongo, A.; Mottet, M.; Weber, V.; Laino, T. Comparison of computational methods for the electrochemical stability window of solid-state electrolyte materials. J. Mater. Chem. A 2020, 8, 1347-1359. [CrossRef]

132. Chen, L.; Venkatram, S.; Kim, C.; Batra, R.; Chandrasekaran, A.; Ramprasad, R. Electrochemical Stability Window of Polymeric Electrolytes. Chem. Mater. 2019, 31, 4598-4604. [CrossRef]

133. Schwietert, T.K.; Arszelewska, V.A.; Wang, C.; Yu, C.; Vasileiadis, A.; De Klerk, N.J.J.; Hageman, J.; Hupfer, T.; Kerkamm, I.; $\mathrm{Xu}, \mathrm{Y}$; ; et al. Clarifying the relationship between redox activity and electrochemical stability in solid electrolytes. Nat. Mater. 2020, 19, 428-435. [CrossRef]

134. Thompson, T.; Yu, S.; Williams, L.; Schmidt, R.D.; Garcia-Mendez, R.; Wolfenstine, J.; Allen, J.; Kioupakis, E.; Siegel, D.; Sakamoto, J. Electrochemical Window of the Li-Ion Solid Electrolyte $\mathrm{Li}_{7} \mathrm{La}_{3} \mathrm{Zr}_{2} \mathrm{O}_{12}$. ACS Energy Lett. 2017, 2, 462-468. [CrossRef]

135. Tian, Y.; Shi, T.; Richards, W.D.; Li, J.; Kim, J.C.; Bo, S.-H.; Ceder, G. Compatibility issues between electrodes and electrolytes in solid-state batteries. Energy Environ. Sci. 2017, 10, 1150-1166. [CrossRef]

136. Dahn, J.R.; Burns, J.C.; Stevens, D.A. Importance of Coulombic Efficiency Measurements in R\&D Efforts to Obtain Long-Lived Li-Ion Batteries. Electrochem. Soc. Interface 2016, 25, 75-78. [CrossRef]

137. Becking, J.; Gröbmeyer, A.; Kolek, M.; Rodehorst, U.; Schulze, S.; Winter, M.; Bieker, P.; Stan, M.C. Lithium-Metal Foil Surface Modification: An Effective Method to Improve the Cycling Performance of Lithium-Metal Batteries. Adv. Mater. Interfaces 2017, 4, 1700166. [CrossRef]

138. Storelli, A.; Rousselot, S.; Alzate-Carvajal, N.; Pelé, V.; Dolle, M. On the Importance of Li Metal Morphology on the Cycling of Lithium Metal Polymer Cells. J. Electrochem. Soc. 2021, 168, 040505. [CrossRef]

139. Rynne, O.; Dubarry, M.; Molson, C.; Nicolas, E.; Lepage, D.; Prébé, A.; Aymé-Perrot, D.; Rochefort, D.; Dollé, M. Exploiting Materials to Their Full Potential, a Li-Ion Battery Electrode Formulation Optimization Study. ACS Appl. Energy Mater. 2020, 3 , 2935-2948. [CrossRef] 
140. Lou, S.; Liu, Q.; Zhang, F.; Liu, Q.; Yu, Z.; Mu, T.; Zhao, Y.; Borovilas, J.; Chen, Y.; Ge, M.; et al. Insights into interfacial effect and local lithium-ion transport in polycrystalline cathodes of solid-state batteries. Nat. Commun. 2020, 11, 1-10. [CrossRef]

141. Banerjee, A.; Wang, X.; Fang, C.; Wu, E.A.; Meng, Y.S. Interfaces and Interphases in All-Solid-State Batteries with Inorganic Solid Electrolytes. Chem. Rev. 2020, 120, 6878-6933. [CrossRef]

142. Doux, J.-M.; Yang, Y.; Tan, D.H.S.; Nguyen, H.; Wu, E.A.; Wang, X.; Banerjee, A.; Meng, Y.S. Pressure effects on sulfide electrolytes for all solid-state batteries. J. Mater. Chem. A 2020, 8, 5049-5055. [CrossRef] 